\title{
Regulation of Persistent Na Current by Interactions between $\beta$ Subunits of Voltage-Gated Na Channels
}

\author{
Teresa K. Aman, ${ }^{1}$ Tina M. Grieco-Calub, ${ }^{1}$ Chunling Chen, ${ }^{3}$ Raffaella Rusconi, ${ }^{3}$ Emily A. Slat, ${ }^{3}$ Lori L. Isom,,${ }^{3}$ and \\ Indira M. Raman ${ }^{1,2}$ \\ ${ }^{1}$ Interdepartmental Neuroscience Program and 2Department of Neurobiology and Physiology, Northwestern University, Evanston, Illinois 60208, and \\ ${ }^{3}$ Department of Pharmacology, University of Michigan, Ann Arbor, Michigan 48109
}

The $\beta$ subunits of voltage-gated Na channels (Scnxb) regulate the gating of pore-forming $\alpha$ subunits, as well as their trafficking and localization. In heterologous expression systems, $\beta 1, \beta 2$, and $\beta 3$ subunits influence inactivation and persistent current in different ways. To test how the $\beta 4$ protein regulates Na channel gating, we transfected $\beta 4$ into HEK (human embryonic kidney) cells stably expressing $\mathrm{Na}_{V}$ 1.1. Unlike a free peptide with a sequence from the $\beta 4$ cytoplasmic domain, the full-length $\beta 4$ protein did not block open channels. Instead, $\beta 4$ expression favored open states by shifting activation curves negative, decreasing the slope of the inactivation curve, and increasing the percentage of noninactivating current. Consequently, persistent current tripled in amplitude. Expression of $\beta 1$ or chimeric subunits including the $\beta 1$ extracellular domain, however, favored inactivation. Coexpressing $\mathrm{Na}_{\mathrm{v}} 1.1$ and $\beta 4$ with $\beta 1$ produced tiny persistent currents, indicating that $\beta 1$ overcomes the effects of $\beta 4$ in heterotrimeric channels. In contrast, $\beta 1_{\mathrm{C} 121 \mathrm{~W}}$, which contains an extracellular epilepsy-associated mutation, did not counteract the destabilization of inactivation by $\beta 4$ and also required unusually large depolarizations for channel opening. In cultured hippocampal neurons transfected with $\beta 4$, persistent current was slightly but significantly increased. Moreover, in $\beta 4$-expressing neurons from $S c n 1 b$ and $S c n 1 b / S c n 2 b$ null mice, entry into inactivated states was slowed. These data suggest that $\beta 1$ and $\beta 4$ have antagonistic roles, the former favoring inactivation, and the latter favoring activation. Because increased $\mathrm{Na}$ channel availability may facilitate action potential firing, these results suggest a mechanism for seizure susceptibility of both mice and humans with disrupted $\beta 1$ subunits.

Key words: resurgent; $\mathrm{Na}_{\mathrm{V}} \beta 4 ; \mathrm{Scn} 4 \mathrm{~b}$; Scn1b; Scn1a; GEFS +; epilepsy; inactivation; Purkinje; CA3

\section{Introduction}

Ionic current through tetrodotoxin (TTX)-sensitive, voltagegated $\mathrm{Na}$ channels generates the upstroke of most neuronal action potentials. In voltage-clamped neurons, step depolarizations evoke rapidly activating and inactivating "transient" Na currents that are grossly similar across cells. Nevertheless, neurons differ in the amplitude of "persistent" Na current remaining after transient currents inactivate (Crill, 1996; Magistretti et al., 1999) and in the expression of "resurgent" current evoked by repolarization from positive potentials (Raman and Bean, 1997; Do and Bean, 2003; Afshari et al., 2004). By increasing channel opening and availability at subthreshold voltages, persistent and resurgent currents generally increase firing rates (Stafstrom et al., 1984;

Received Sept. 21, 2008; revised Dec. 30, 2008; accepted Jan. 6, 2009.

This work was supported by National Institutes of Health Grants NS39395 (I.M.R.) and MH059980 (L.L.I.), by National Research Service Award F31 NS057866 (T.K.A.), and by a grant from the Partnership for Pediatric Epilepsy (L.L.I.). We thank Dr. Ken Tovar for teaching us culturing methods. We are also grateful to Jason Pugh, Nan Zheng, Jason Bant, and Mark Benton for helpful discussion.

Correspondence should be addressed to Indira M. Raman, Department of Neurobiology and Physiology, 2205 Tech Drive, Northwestern University, Evanston, IL 60208. E-mail: i-raman@northwestern.edu.

T. M. Grieco-Calub's present address: School of Allied Health and Communicative Disorders, Northern Illinois University, DeKalb, IL 60115.

R. Rusconi's present address: Department of Neurophysiopathology, Besta Neurological Institute, 20133 Milan, Italy.

DOI:10.1523/JNEUROSCI.4531-08.2009

Copyright $\odot 2009$ Society for Neuroscience $\quad$ 0270-6474/09/292027-16\$15.00/0
Khaliq et al., 2003). In fact, drugs such as phenytoin and carbamazepine, which stabilize inactivation and minimize persistent current (Chao and Alzheimer, 1995; Kuo et al., 1997; Lampl et al., 1998), are used clinically to control seizures.

"Window" current, which flows at voltages at which activation occurs but inactivation is submaximal, contributes to persistent current (Attwell et al., 1979). At more positive voltages, persistent current flows through $\mathrm{Na}$ channels that occasionally fail to inactivate (Alzheimer et al., 1993; Brown et al., 1994) and/or have an incomplete equilibrium occupancy of inactivated states (Taddese and Bean, 2002). Resurgent current, in contrast, results from an open-channel blocking protein that binds channels at positive voltages. After repolarization, the blocker unbinds, permitting current to flow briefly (Raman and Bean, 2001).

The molecular basis for $\mathrm{Na}$ current diversity depends partly on subunit composition. In central neurons, the pore-forming $\alpha$ subunits that carry $\mathrm{Na}$ current include $\mathrm{Na}_{\mathrm{V}} 1.1, \mathrm{Na}_{\mathrm{V}} 1.2$, and $\mathrm{Na}_{\mathrm{V}} 1.6$ (Felts et al., 1997; Smith et al., 1998). These associate with $\beta$ subunits, which regulate both trafficking and gating. $\beta 1$ accelerates fast inactivation (Isom et al., 1992, 1995a; Chen and Cannon, 1995); $\beta 3$ increases persistent current (Qu et al., 2001); $\beta 2$ can do both (Isom et al., 1995b; Qu et al., 2001). The $\beta 4$ subunit (Yu et al., 2003) is indirectly implicated in resurgent current, because its cytoplasmic domain mimics the action of the endogenous blocking protein (Grieco et al., 2005), but this behavior has 
not been replicated in heterologous expression systems (Chen et al., 2008).

The varied effects of $\beta$ subunits on gating raise the question of whether interactions among subunits generate Na channel complexes with distinct properties. To explore this possibility, we studied how $\beta 4$ modulates $\mathrm{Na}$ currents when expressed either alone or with other $\beta$ subunits. In both expression systems and hippocampal neurons, $\beta 4$ overexpression favored channel activation and increased persistent current. This effect was antagonized, and inactivation was accelerated by coexpression of $\beta 1$, but not $\beta 1_{\mathrm{C} 121 \mathrm{~W}}$, a mutant subunit linked to generalized epilepsy with febrile seizures plus (GEFS+) (Wallace et al., 1998, 2002). Activation was facilitated, and inactivation rates were slowed in $\beta 4$-expressing neurons of $S c n 1 b$ null mice. These data suggest that $\beta 1$ has a dominant role in reducing $\mathrm{Na}$ channel activity, raising the possibility that disruption of $\beta 1$ in inherited epilepsies may slow inactivation rates in some neurons, thereby contributing to the excessive firing associated with seizure disorders.

\section{Materials and Methods}

HEK-293 cells. HEK-293 cells stably transfected with $\mathrm{Na}_{\mathrm{V}} 1.1$ (HEK$\mathrm{Na}_{\mathrm{V}} 1.1$ cells) were obtained from GlaxoSmithKline under a Materials Transfer Agreement. These cells provide a non-neuronal mammalian cell line containing neuronal $\mathrm{Na}$ channels, in which proteins associated with neuronal $\mathrm{Na}$ channels can be easily transfected and studied. Like other cells of adrenal origin, $\mathrm{HEK}-\mathrm{Na}_{\mathrm{V}} 1.1$ cells express the splice variant $\beta 1 \mathrm{~B}$ (Moran et al., 2000); however, Western blots indicate no detectable expression of $\beta 1 \mathrm{~A}$ (hereafter called $\beta 1$ ), $\beta 2, \beta 3$, or $\beta 4$ in these cells (data not shown; R. Rusconi and L. L. Isom, unpublished observation). One day before recording or transfection, cells were plated on poly-L-lysinecoated coverslips at $\sim 5000-10,000$ cells per coverslip.

CA3 hippocampal cultures. Cultures were prepared according to a protocol modified from Tovar and Westbrook (2002). All chemicals, except as noted, were from Sigma-Aldrich. Neurons and glia were prepared by dissecting the CA3 region of the hippocampus from C57BL/6 mice, aged postnatal day $0(\mathrm{P} 0)$, in cold $\mathrm{D} 1$ dissection saline $(140 \mathrm{~mm} \mathrm{NaCl}, 5 \mathrm{~mm}$ $\mathrm{KCl}, 0.1 \mathrm{~mm} \mathrm{Na}_{2} \mathrm{HPO}_{4}, 2.2 \mathrm{~mm} \mathrm{KH_{2 }} \mathrm{PO}_{4}, 5$ mM HEPES, 4 mm sucrose, 30 $\mathrm{mm}$ glucose, $10 \mu \mathrm{l} / \mathrm{ml}$ penicillin/streptomycin, and $0.001 \%$ phenol red). Tissue was incubated in $20 \mathrm{U} / \mathrm{ml}$ papain (Worthington Biochemicals), $1.7 \mathrm{~mm}$ cysteine, $100 \mu \mathrm{M} \mathrm{CaCl}_{2}$, and $50 \mu \mathrm{M}$ EDTA in the D1 solution (pH 7.3 with $\mathrm{NaOH}$ ) for $40 \mathrm{~min}$ at $32^{\circ} \mathrm{C}$. The tissue was washed in neuronal medium [ $5 \%$ heat-inactivated fetal calf serum (HyClone), $20 \mathrm{~mm}$ glucose, and $0.5 \mathrm{~mm}$ Glutamax (Invitrogen) in Minimum Essential Medium (Invitrogen)] with $2.5 \mathrm{mg} / \mathrm{ml}$ each of bovine serum albumin and trypsin inhibitor. The tissue was then triturated with polished Pasteur pipettes to release individual cells. To make glial beds, cells were plated at a concentration of 100,000 $\pm 25,000$ cells per coverslip onto poly-L-lysine-coated coverslips coated with collagen (Cohesion) and were allowed to grow to confluence. One week later, surviving neurons were killed by excitotoxicity with (in mM) 0.2 glutamate, $2 \mathrm{CaCl}_{2}, 165 \mathrm{NaCl}, 5 \mathrm{KCl}$, and 5 HEPES, and freshly isolated cells (neurons and glia) were plated onto the glial beds at the same concentration as above. To prevent further glial cell proliferation in neuronal cultures, $5 \mu \mathrm{M}$ cytosine arabinoside was added after cells were plated. Neurons were transfected at $2-3 \mathrm{~d}$ in vitro, and recordings were made at $6-15 \mathrm{~d}$ after transfection.

$\beta 4$ clones, chimeras, and $\beta$ subunit mutations. A PCR strategy was used to generate $\beta 4 \mathrm{cDNA}$. Two sets of oligonucleotide primers were designed from the rat $S c n 4 b$ mRNA sequence in GenBank, a set of external primers (forward, 5'-CTGTGCACACTGTCCTATCCAAGC-3'; reverse, 5' CACATCTCAGACAGGACTCGGCATC-3') and a set of internal primers (forward, 5' -CAACTCGAGCGCTCCGGAGAGAACAGGAC-3'; reverse, $\quad 5^{\prime}$-ATCGAATTCACCATCAGAAAGTGAGGCTC- $\left.3^{\prime}\right)$. The external primer set was used to perform reverse transcription-PCR from rat brain total RNA. Then, using an aliquot of the first PCR product as a template, a second round of PCR was performed using the set of internal primers. With this design, a PCR product of $\sim 700 \mathrm{bp}$ was amplified. This PCR product was digested with Xho I and EcoRI and subcloned into
pcDNA 3.1/Zeo(-). The sequence of the cDNA insert was found to be identical to the GenBank sequence. To facilitate stable mammalian cell expression with sodium channel $\alpha$ subunits, the $\beta 4 \mathrm{cDNA}$ was subsequently subcloned into pcDNA3.1/Hygro(-).

PCR strategies were used to generate the $\beta 1 / 4$ and $\beta 2 / 4$ subunit chimeras. For generation of $\beta 1 / 4$, cDNA fragments encoding the extracellular and transmembrane domain of $\beta 1$ and the intracellular domain of $\beta 4$ were amplified from plasmids containing the rat $S c n 1 b$ or rat $S c n 4 b$ cDNAs, respectively. The $\beta 1$ domain was generated with the following primer set: $\beta 1$-forward, $5^{\prime}$-ATCTCCTGTCGCCGCGCTCT-3'; $\beta 1 / 4$ reverse, $5^{\prime}$-AGTGATGAGCTTCTTGTAGCAGTA- $3^{\prime}$. The $\beta 4$ domain was generated with the following primer set: $\beta 1 / 4$-forward, $5^{\prime}$-TACTGCTACAAGAAGCTCATCACT- $3^{\prime}$; $\beta 4$-reverse, $5^{\prime}$-CAGGGCCTCACACTTTTGTGG-3'. The resulting PCR fragments were analyzed by agarose gel electrophoresis and purified. $\beta 1 / 4$-reverse and $\beta 1 / 4$-forward contained complementary, overlapping sequences such that the purified PCR fragments could be denatured, annealed, and used as a template to generate the final chimera using $\beta 1$-forward and $\beta 4$-reverse as PCR primers.

$\beta 2 / 4$, containing the extracellular and transmembrane domains of $\beta 2$ and the intracellular domain of $\beta 4$, was generated using a similar strategy, substituting rat $S c n 2 b$ cDNA and the following set of primers for amplification of $\beta 2$ : $\beta 2$-forward, 5'-ATGCACAGGGATGCCTGG-3'; $\beta 2 / 4$-reverse, $5^{\prime}$-CAGCAACAGCACACATTT- $3^{\prime}$. The $\beta 4$ domain was generated with the following primer set: $\beta 2 / 4$-forward, $5^{\prime}$-AAATGTGTGCTGTTGCTG- ${ }^{\prime} ; \beta 4$-reverse, as described above. The $\beta 2 / 4$ chimera was then generated from the purified fragments by PCR using $\beta 2$ forward and $\beta 4$-reverse primers.

The resulting chimeras were cloned into pcDNA3.1/Hygro $(-)(\beta 1 / 4)$ or pcDNA3.1/Zeo $(-)(\beta 2 / 4)$ for use in mammalian cell expression. The integrity of each construct was confirmed by DNA sequencing. The amino acid sequence of $\beta 1 / 4$ is as follows (underlined residues indicate $\beta 4$ sequence): MGTLLALVVG AVLVSSAWGG CVEVDSETEA VYGMTFKILC ISCKRRSETT AETFTEWTFR GKGTEEFVKI LRYENEVLQL EEDERFEGRV VWNGSRGTKD LQDLSIFITN VTYNHSGDYE CHVYRLLFFD NYEHNTSVVK KIHLEVVDKA NRDASIVSEI MMYVLIVVLT IWLVAEMVYC YKKLITFILK KTREKKKEC1 VSSGNDNTE NGLPGSKAEE KPPTKV. The amino acid sequence of $\beta 2 / \beta 4$ is as follows (underlined residues indicate $\beta 4$ sequence): MHRDAWLPRP AFSLTGLSLF FSLVPSGRSM EVTVPTTLSV LNGSDTRLPC TFNSCYTV KQFSLNWTYQ ECSNCSEEMF LQFRMKIINL KLERFGDRVE FSGNPSKYDV SVTLKNVQLE DEGIYNCYIT NPPDRHRGHG KIYLQVLLEV PPERDSTVAV IVGASVGGFL AVVILVLMV KCVLLLKKLI TFILKKTREK KKECLVSSSG NDNTENGLPG SLAEEKPPTK V.

Transfection and identification of transfected cells. HEK-Na 1.1 cells and CA3 pyramidal neurons were transfected with Lipofectamine (Invitrogen) according to Dalby et al. (2004). The cDNA for the $\beta$ subunit(s) of interest and cDNA for green fluorescent protein (GFP; Clontech) was added to cells in a 5:1 concentration ratio, so that GFP-labeled cells would be highly likely to be transfected with the $\beta$ subunit. Lipofectamine $(4 \mu \mathrm{l})$ was added to $50 \mu \mathrm{l}$ of Opti-MEM (Invitrogen) and incubated for $30 \mathrm{~min}$ at room temperature. Separately, 1-2 $\mu \mathrm{g}$ of cDNA was added to $50 \mu \mathrm{l}$ of Opti-MEM and incubated for $5 \mathrm{~min}$. The cDNA and Lipofectamine solutions were then mixed for $20 \mathrm{~min}$ at room temperature. This mixture was added to the cells for $3 \mathrm{~h}$, after which the medium was exchanged. Recordings were made at least $24 \mathrm{~h}$ after transfection. GFP-labeled cells were identified with an X-Cite 120 Fluorescence Illumination System (Exfo) on a Nikon Eclipse TE2000-U microscope. Control data from nontransfected cells and cells transfected with GFP alone were indistinguishable and were therefore pooled.

Scn $1 b$ and Scn $2 b$ null mice. Scn $1 b(\beta 1)$ and $\operatorname{Scn} 2 b(\beta 2)$ null mice were generated as described by Chen et al. $(2002,2004)$. Congenic strains were created by repeated backcrossing of $S c n 1 b^{+/-}$or $S c n 2 b^{+/-}$mice to C57BL/6 (Silva et al., 1997) for $>10$ generations. Double null mice $\left(S c n 1 b / S c n 2 b\right.$ null) were obtained by mating N10 Scn $1 b^{+/-}$with N10 $S c n 2 b^{-1-}$ mice to generate $S c n 1 b^{+/-} / S c n 2 b^{-1-}$ mice. Breeding these mice produced offspring that included the double null mutants. Experiments were done blind to genotype. Genotypes of all mice from which 
neurons were isolated for electrophysiological recordings were confirmed by PCR (Chen et al., 2002, 2004).

Purkinje cell dissociation. Cerebellar Purkinje cells were acutely dissociated from Scn $1 \mathrm{~b}$ and Scn2b null and littermate control mice (P14-P19) as described previously (Raman et al., 1997; Grieco et al., 2005). Briefly, mice were anesthetized with halothane, and the superficial layers of the cerebellum were removed and minced in ice-cold dissociation solution containing $82 \mathrm{mM} \mathrm{Na}_{2} \mathrm{SO}_{4}, 30 \mathrm{~mm} \mathrm{~K}_{2} \mathrm{SO}_{4}, 5 \mathrm{~mm} \mathrm{MgCl}_{2}, 10 \mathrm{~mm}$ HEPES, $10 \mathrm{~mm}$ glucose, and $0.001 \%$ phenol red ( $\mathrm{pH} 7.4$ with $\mathrm{NaOH}$ ). The tissue was incubated in dissociation solution ( $3 \mathrm{mg} / \mathrm{ml}$ protease XXIII, $\mathrm{pH} 7.4$ ) for $7 \mathrm{~min}$ at $31^{\circ} \mathrm{C}$ with $100 \%$ oxygen blowing over the surface, washed, and microdissected in dissociation solution with $1 \mathrm{mg} / \mathrm{ml}$ each of bovine serum albumin and trypsin inhibitor, $\mathrm{pH}$ 7.4. The tissue was then transferred to Tyrode's solution (in mM: $150 \mathrm{NaCl}, 4 \mathrm{KCl}, 2 \mathrm{CaCl}_{2}, 2 \mathrm{MgCl}_{2}, 10$ HEPES, and 10 glucose, $\mathrm{pH}$ 7.4, with $\mathrm{NaOH}$ ). Individual neurons were released by trituration with polished Pasteur pipettes. Cells settled in the recording dish for $1 \mathrm{~h}$, and recordings were made $1-6 \mathrm{~h}$ after trituration.

Recording and analysis. Borosilicate pipettes (1.8-3 M 2 ; A-M Systems) were coated with Sylgard or wrapped with Parafilm and filled with intracellular solution containing (in mM) $108 \mathrm{CsCH}_{3} \mathrm{SO}_{3}, 1.8 \mathrm{NaCl}, 1.8 \mathrm{MgCl}_{2}, 9$ HEPES, 1.8 EGTA, 48 sucrose, 4.5 tetraethylammonium (TEA)-Cl, 14 Triscreatine $\mathrm{PO}_{4}, 4 \mathrm{MgATP}$, and 0.3 TrisGTP (pH 7.4 with $\mathrm{CsOH}$ ). For experiments on Purkinje cells, the same solution was used, but without TEA and with $9 \mathrm{NaCl}$. As indicated, the $\beta 4$ peptide ( $200 \mu \mathrm{M}$; Open Biosystems), which consists of amino acids $154-167$ from the cytoplasmic tail of the $\beta 4$ protein (Grieco et al., 2005), was added to the intracellular solution. Whole-cell voltage-clamp recordings were made with an Axopatch 200B amplifier (Molecular Devices). Series resistance was compensated $>85 \%$. Data were obtained with pClamp 9.0 (Molecular Devices). Solutions were exchanged by positioning cells in front of a pair of gravity-driven flow pipes. For HEK$\mathrm{Na}_{\mathrm{V}} 1.1$ and CA3 cells, the first pipe contained either Tyrode's solution with (in mM) $10 \mathrm{TEA}-\mathrm{Cl}, 0.3 \mathrm{CdCl}_{2}$ or $150 \mathrm{NaCl}, 10 \mathrm{TEA}-\mathrm{Cl}, 0.3 \mathrm{CdCl}_{2}, 2 \mathrm{BaCl}_{2}$, 10 HEPES, and 10 glucose. The second pipe contained the control solution, but with 900 nм TTX (Alomone Labs) to block Na currents. For Purkinje cells, pipes contained the same solutions, except that $\mathrm{NaCl}$ was reduced to 50 $\mathrm{mm}$ and replaced with equimolar TEA-Cl to achieve better voltage clamp of the very large somatic Na currents. Currents were not leak subtracted. To isolate TTX-sensitive Na current, raw records obtained in TTX were subtracted from those recorded in control solutions (without TTX). Cells that showed evidence that leak currents changed between recordings in control and TTX were discarded.

Data were analyzed with IGOR-Pro (Wavemetrics) and are reported as mean \pm SEM. Conductance-voltage plots were measured by dividing peak currents in each cell by the driving force to yield conductances, which were normalized and fit with a Boltzmann function, $G / G_{\max }=$ $1 /\left(1+\exp \left(-\left(V-V_{1 / 2}\right) / k\right)\right)$, where $G$ is conductance, $G_{\max }$ is the maximal conductance, $V_{1 / 2}$ is the half-maximal voltage of activation, and $k$ is the slope factor. Voltage control in each cell was assessed by verifying that conductance-voltage plots were continuous and that the rise time of currents evoked by step depolarizations decreased gradually. Cells without these attributes were excluded from the analysis. Steady-state inactivation (availability) curves were normalized to peak current and fit with a modified Boltzmann of the form $I=F_{\mathrm{ss}}+\left(1-F_{\mathrm{ss}}\right) /(1+\exp ((V-$ $\left.\left.V_{1 / 2}\right) / k\right)$ ), where $I$ is the normalized current at $0 \mathrm{mV}, V_{1 / 2}$ is the halfmaximal voltage of inactivation, $k$ is the slope factor, and $F_{\mathrm{ss}}$ is the fraction of steady-state or noninactivating current (reported as a percentage). The percentage of persistent or resurgent current was calculated by dividing the current amplitude by the peak transient current at $0 \mathrm{mV}$. If conductance was not maximal at $0 \mathrm{mV}$, the current at $0 \mathrm{mV}$ was corrected by dividing by the fractional conductance at $0 \mathrm{mV}$. Statistical significance was assessed with Student's two-tailed $t$ tests, the Mann-Whitney $U$ test, or two-way repeated-measures ANOVAs, with cell condition and voltage as variables (SPSS); main effects are reported. Cells from which data were not obtained at all voltages were excluded from ANOVAs but were included in plots of mean data. In Figure 1C, ANOVAs included measurements only at voltages from -40 to $0 \mathrm{mV}$ because data was not gathered at +10 and $+20 \mathrm{mV}$ in all cells. For all statistical tests, $p$ values are reported, and significance is taken as 0.05 . Capacitative artifacts have been digitally reduced in most figures.
Coimmunoprecipitation. HEK-293T cells, cultured as described previously (Rusconi et al., 2007), were transfected with $10 \mu \mathrm{g}$ of hNav1.1pCDM8 (Rusconi et al., 2007) plus $4 \mu \mathrm{g}$ of rat $\beta 1$-V5-pcDNA3.1Hygro - ( $\beta 1 \mathrm{cDNA}$ containing a C-terminal V5 epitope tag) or $4 \mu \mathrm{g}$ of rat $\mathrm{C} 121 \mathrm{~W} \beta 1$-V5-pcDNA3.1/Hygro $(-)\left(\beta 1_{\mathrm{C} 121 \mathrm{~W}} \mathrm{cDNA}\right.$ containing a C-terminal V5 epitope tag) or rat $\beta 4$-pcDNA3.1/Hygro(-) using the calcium phosphate method (Rusconi et al., 2007) and allowed to grow for $36 \mathrm{~h}$. Protein A- or protein G-Sepharose beads (Sigma) were prepared by washing three times with $\mathrm{PBS}$ at $4^{\circ} \mathrm{C}$, followed by resuspension in $250 \mu \mathrm{l}$ of dilution buffer [DB; $60 \mathrm{~mm}$ Tris/ $\mathrm{HCl}, \mathrm{pH}$ 7.5, $180 \mathrm{~mm} \mathrm{NaCl}, 1.25 \%$ Triton X-100, and 6 mm EDTA, pH 8, containing Complete Mini protease inhibitor tablets (Roche) at two times the manufacturer's recommended concentration] at $4^{\circ} \mathrm{C}$. The beads were then incubated overnight at $4^{\circ} \mathrm{C}$ with $4 \mu \mathrm{g}$ of polyclonal (rabbit) pan $\mathrm{Na}^{+}$channel antibody (Sigma) or with $4 \mu \mathrm{g}$ of monoclonal (mouse) anti-V5 antibody (AbD; Serotec), or with $4 \mu \mathrm{g}$ of rabbit or mouse IgG as a negative control. The supernatant was removed, and the beads were resuspended in DB containing $2 \%$ bovine serum albumin followed by incubation for $3 \mathrm{~h}$ at $4^{\circ} \mathrm{C}$ to saturate nonspecific binding sites. The transfected cells were detached from the culture dishes using $50 \mathrm{~mm}$ Tris and $10 \mathrm{~mm}$ EGTA, pH 8, and centrifuged at $5000 \mathrm{rpm}$ in a microfuge for $10 \mathrm{~min}$ at $4^{\circ} \mathrm{C}$. The cell pellet was resuspended in DB for cell lysis. After $30 \mathrm{~min}$ of lysis on ice, a $10 \mathrm{~min}$ centrifugation at 10,000 rpm in a microfuge was performed to remove insoluble material. The resulting supernatant was added to the beads and incubated by rotating end-over-end for $3 \mathrm{~h}$ at $4^{\circ} \mathrm{C}$. The beads were then washed three times with washing buffer (50 mM Tris, $\mathrm{pH} 7.5,150 \mathrm{~mm}$ $\mathrm{NaCl}, 0.1 \%$ Triton X-100, $0.02 \%$ SDS, and 5 mm EDTA, pH 8, containing Complete Mini protease inhibitor tablets at two times the manufacturer's recommended concentration), followed by one wash with the same buffer but without Triton X-100. Samples were then separated by SDSPAGE on $8.5 \%$ polyacrylamide gels and transferred to nitrocellulose for Western blot analysis as described previously (Brackenbury et al., 2008). Immunoblots were probed with anti-V 5 or anti- $\beta 4$ antibody (Wong et al., 2005), as indicated, and detected with Westfemto Chemiluminescent reagent (Pierce).

\section{Results \\ B4 expression increases persistent $\mathrm{Na}$ current in HEK-Na 1.1 cells}

To test the influence of the $\mathrm{Na}$ channel $\beta 4$ subunit on the properties of Na currents, TTX-sensitive currents were recorded from human embryonic kidney (HEK) cells stably expressing $\mathrm{Na}_{\mathrm{V}} 1.1$ with and without transfection of $\beta 4$. Activation curves were obtained by evoking transient $\mathrm{Na}$ currents from $-110 \mathrm{mV}$ with depolarizing steps in $5 \mathrm{mV}$ increments. Figure $1 A$ (top) illustrates currents and the activation curve from a representative control cell, along with a conductance-voltage curve from a cell transfected with $\beta 4$. Voltage control was assessed in each cell (see Materials and Methods), and all cells included for analysis are shown in supplemental Figure 1 (available at www.jneurosci.org as supplemental material). Neither the slope factors $(k)$ nor the maximum conductances $\left(G_{\max }\right)$ were significantly changed by the expression of $\beta 4$ (Fig. $1 A$, bottom) (control vs $\beta 4: k=4.9 \pm$ 0.3 vs $5.2 \pm 0.3 \mathrm{mV}, p=0.7 ; G_{\max }=45 \pm 8$ vs $38 \pm 7 \mathrm{nS}, p=0.4$; $n=15,13)$. The half-maximal voltage of activation $\left(V_{1 / 2}\right)$, however, was sensitive to $\beta 4$ expression. In control cells, $V_{1 / 2}$ was $-16.8 \pm 0.9 \mathrm{mV}$, and $\beta 4$ expression negatively shifted this value to $-21.8 \pm 1.0 \mathrm{mV}(p=0.001)$ (Fig. $1 A$, bottom). Boltzmann curves with mean fit parameters (Fig. $1 A$, bottom right) illustrate the average effect of $\beta 4$ expression on activation. The observation that the properties of $\mathrm{Na}$ currents were modified after $\beta 4$ transfection suggests that $\beta 4$ was successfully incorporated into channel complexes. A similar leftward shift of the activation curve has been reported when $\beta 4$ is coexpressed with $\mathrm{Na}_{\mathrm{V}} 1.2$ in tsA-201 cells (Yu et al., 2003).

Next, we measured steady-state inactivation (availability) of 

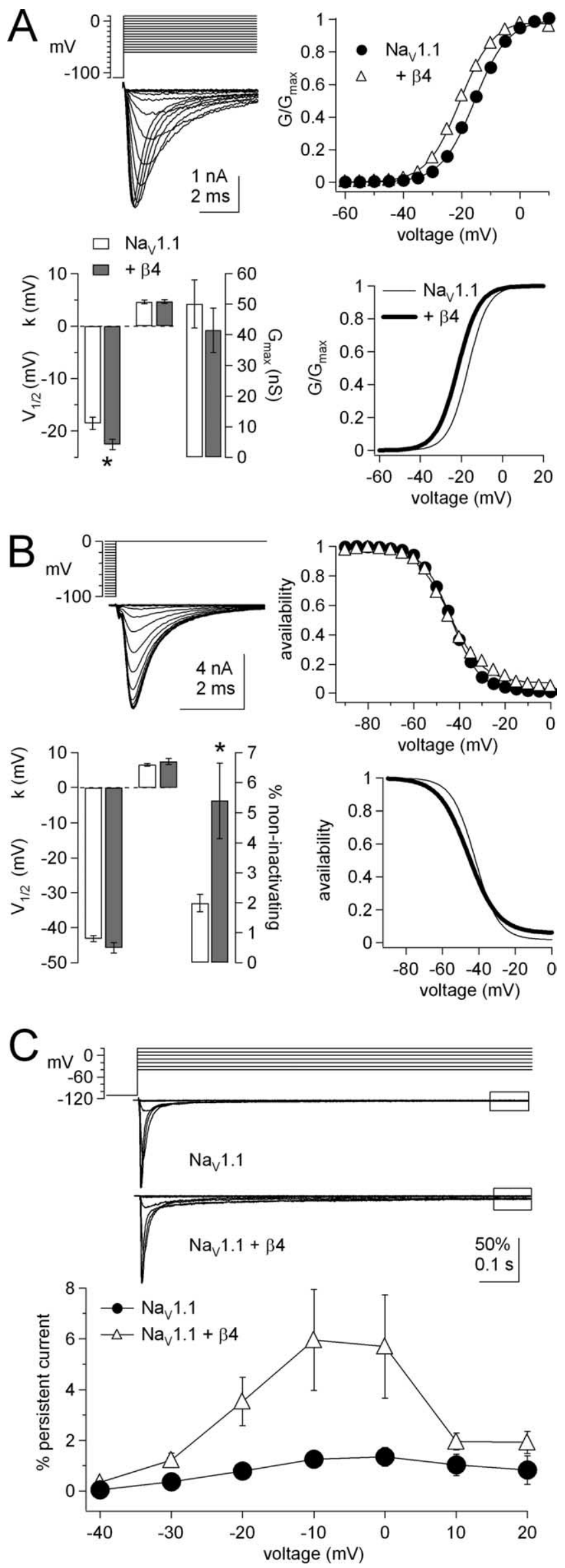

$\mathrm{Na}$ currents by applying $100 \mathrm{~ms}$ conditioning steps followed by steps to $0 \mathrm{mV}$. Peak currents evoked at $0 \mathrm{mV}$ were normalized, plotted as availability versus voltage, and fit with Boltzmann functions modified to incorporate a noninactivating component. Data for a representative control cell, along with availability for a $\beta 4$-transfected cell, are shown in Figure $1 B$ (top). Mean values for fits and Boltzmann curves with mean fit parameters are shown in Figure $1 B$ (bottom). With $\beta 4$ expression, $V_{1 / 2}$ shifted slightly negative, and the slope factor increased slightly (control vs $\beta 4$ : $V_{1 / 2}=-42.1 \pm 0.7$ vs $-45.7 \pm 1.7 \mathrm{mV}, p=0.07 ; k=6.4 \pm$ 0.4 vs $8.1 \pm 1.0 \mathrm{mV}, p=0.13 ; n=15,13)$. The most substantial change, however, was that the $\beta 4$-transfected cells had an unusually large noninactivating component (control vs $\beta 4: 1.8 \pm 0.3$ vs $5.8 \pm 1.4 \%, p=0.02$ ). These results therefore suggest that $\beta 4$ expression in $\mathrm{HEK}-\mathrm{Na}_{\mathrm{V}} 1.1$ cells destabilizes fast inactivation and instead favors channel opening at $0 \mathrm{mV}$.

Given the increase in availability measured at $0 \mathrm{mV}$, we tested whether $\beta 4$ influenced the amount of persistent $\mathrm{Na}$ current at other voltages by measuring the mean current in the last $10 \mathrm{~ms}$ of the $100 \mathrm{~ms}$ conditioning steps (Fig. 1C). Although the transient current amplitudes were similar with and without $\beta 4$ (control vs $\beta 4:-4.3 \pm 0.8$ vs $-3.9 \pm 0.7 \mathrm{nA}$ at $0 \mathrm{mV} ; n=15,13)$, the persistent current was increased more than threefold in the presence of $\beta 4$ (control vs $\beta 4$ : $-46 \pm 13$ vs $-143 \pm 27 \mathrm{pA}$ at -10 $\mathrm{mV}$ ). To control for variations in current density across cells, the persistent current amplitude was normalized to the peak amplitude of the transient current at $0 \mathrm{mV}$ in each cell (corrected as necessary to represent maximal conductance; see Materials and Methods), and the percentage of persistent current was plotted against voltage. Consistent with the availability curve, $\beta 4$ transfected cells showed more persistent current compared with control cells, with the increase being most pronounced at voltages between -20 and $0 \mathrm{mV}$ (Fig. 1C, open triangles) (significant main effect of condition on current; $F_{(1,26)}=6.9 ; p=0.014$ ).

\section{$\beta 4$ expression is not sufficient to produce resurgent $\mathrm{Na}$ current in $\mathrm{HEK}-\mathrm{Na}_{\mathrm{v}} 1.1$ cells}

Previous work from our group demonstrated that a 14 amino acid sequence from the $\beta 4$ intracellular domain (the " $\beta 4$ pep-

$\leftarrow$

Figure 1. Expression of $\beta 4$ negatively shifts activation and increases the noninactivating component of $\mathrm{Na}$ currents in HEK-Nav 1.1 cells. A, Top left, Representative TTX-sensitive Na currents (bottom) evoked by the activation voltage protocol (top). Top right, Single representative activation curves, plotted as normalized conductance against voltage for a control cell (circles) and a cell transfected with $\beta 4$ (triangles). Parameters are as follows: control: $V_{1 / 2}=$ $-15.6 \mathrm{mV}, k=5.7 \mathrm{mV} ; \beta 4: V_{1 / 2}=-20.6 \mathrm{mV}, k=5.7 \mathrm{mV}$. Bottom left, Mean parameters of fits to data from control $(n=15)$ and $\beta 4$-transfected $(n=13)$ cells. Left bars, $V_{1 / 2}$; middle bars, $k$; right bars, $G_{\max }$. Asterisks in all figures indicate statistical differences from control, unless indicated otherwise. Transfection with $\beta 4$ significantly hyperpolarized the $V_{1 / 2}$ of activation. Bottom right, Boltzmann functions with mean fit parameters. $\boldsymbol{B}$, Top left, Representative TTXsensitive $\mathrm{Na}$ currents (bottom) evoked by the inactivation voltage protocol (top). Top right, Single representative inactivation curves, plotted as normalized current (availability) at $0 \mathrm{mV}$ against conditioning potential, for a control cell (circles) and a cell transfected with $\beta 4$ (triangles). Parameters are as follows: control: $V_{1 / 2}=-43.6 \mathrm{mV}, k=6.4 \mathrm{mV}$; percentage noninactivating is $1.1 \% ; \beta 4: V_{1 / 2}=-44.4 \mathrm{mV}, k=7.4 \mathrm{mV}$; percentage noninactivating is $7.2 \%$. Bottom left, Mean parameters of fits to data from control $(n=15)$ and $\beta 4$-transfected $(n=13)$ cells. Left bars, $V_{1 / 2}$; middle bars, $k$; right bars, percentage of noninactivating current. $\beta 4$ transfection increased the steady-state component of the inactivation curve. Bottom right, Boltzmann functions with mean fit parameters. $C$, Top, Voltage protocol and representative traces evoked in the absence and presence of $\beta 4$ subunit expression. The box indicates the region of the trace in which persistent current was measured. Bottom, Persistent current measured as the mean current in the last $10 \mathrm{~ms}$ of each $100 \mathrm{~ms}$ step, normalized to the peak transient current at $0 \mathrm{mV}$ and plotted versus voltage. $\beta 4$-transfected cells $(n=13)$ had significantly more persistent current than control cells $(n=15)$. Error bars indicate SEM. 

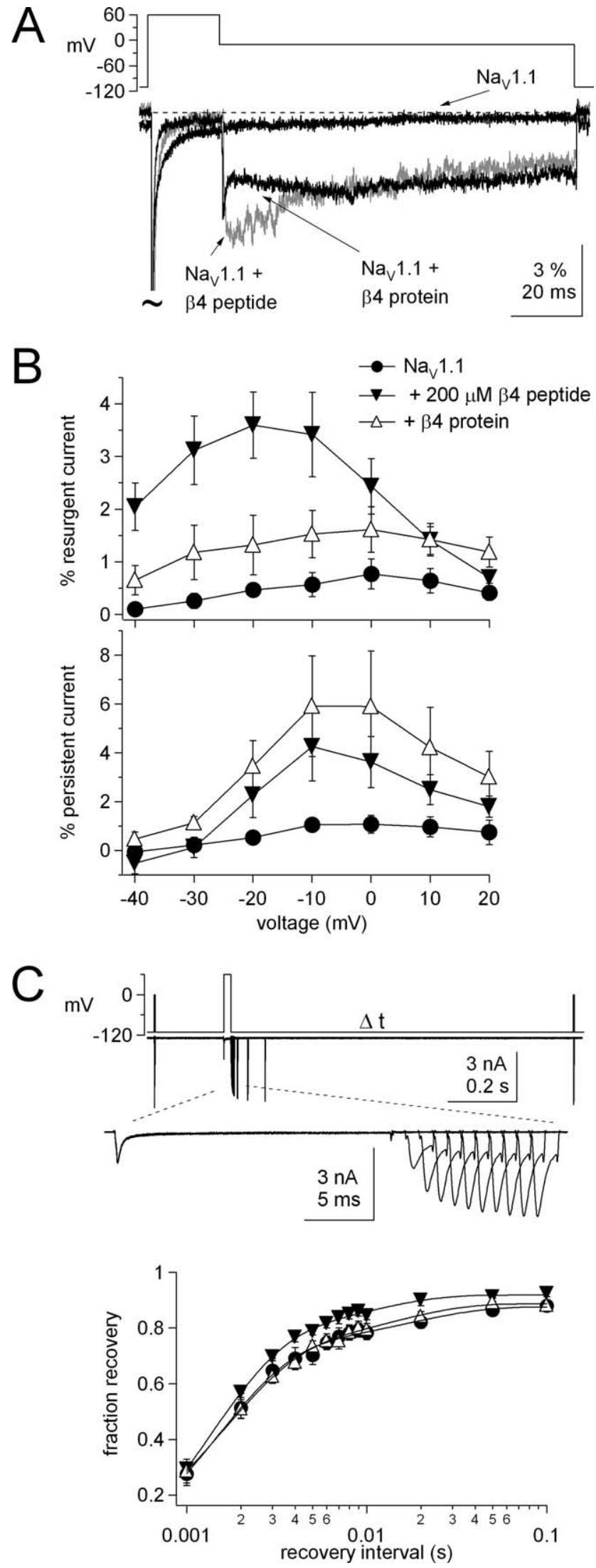

Figure 2. Expression of the $\beta 4$ subunit increases persistent, but not resurgent, Na current. $\boldsymbol{A}$, Voltage protocol and representative traces for each condition, as labeled. Traces were normalized to the peak current evoked at $0 \mathrm{mV}$ in each cell. $\boldsymbol{B}$, Top, Mean peak currents evoked during repolarization after subtraction of the steady-state current at the end of each trace. Currents tide") can bind open $\mathrm{Na}$ channels of neurons in a voltagedependent manner. Channels are blocked by the peptide at positive voltages and become unblocked after repolarization, allowing resurgent $\mathrm{Na}$ current to flow, both in Purkinje neurons after enzymatic removal of their endogenous open-channel blocking protein, or in CA3 neurons, which lack endogenous block (Grieco et al., 2005). To test whether expression of the full-length $\beta 4$ protein might replicate this behavior in HEK$\mathrm{Na}_{\mathrm{V}} 1.1$ cells, we stepped cells to $+60 \mathrm{mV}$ to maximize the possibility of voltage-dependent block and repolarized to potentials between -40 and $+20 \mathrm{mV}$. As expected, in control cells, little current was detectable after repolarization (Fig. $2 A$ ). To verify that $\mathrm{Na}_{\mathrm{V}} 1.1$ channels expressed in HEK cells were capable of undergoing block and unblock in a manner similar to Na channels in their native neuronal environments, we included the $\beta 4$ peptide $(200 \mu \mathrm{M})$ in the recording pipette. In the presence of the peptide, repolarization indeed evoked a current with kinetics resembling native resurgent current in neurons, but with a maximal resurgent current between -10 and $-20 \mathrm{mV}$ rather than at $-30 \mathrm{mV}$ as in neurons (Fig. 2A). This shift is consistent with the fact that the $V_{1 / 2}$ of activation is $\sim 15 \mathrm{mV}$ more depolarized than in neurons (Raman and Bean, 1997). In contrast, with expression of the full-length $\beta 4$ protein, little, if any, resurgent current was evident. Instead, repolarization evoked a brief tail followed by a large steady-state current (Fig. 2A), consistent with the increased noninactivating component observed with step depolarizations.

To quantify these data, the resurgent current was calculated as the difference between the maximal current (after the tail) and the persistent current (at the end of the step). At $-10 \mathrm{mV}$, the current was $-26 \pm 9 \mathrm{pA}$ in control $(n=15),-166 \pm 38 \mathrm{pA}$ with the $\beta 4$ peptide $(n=10)$, and $-30 \pm 5 \mathrm{pA}$ with the $\beta 4$ protein $(n=13)$. Because the mean transient current density in the cells with the peptide $(-5.3 \pm 0.4 \mathrm{nA}$ at $0 \mathrm{mV})$ was slightly greater than in the control and $\beta 4$ protein-expressing cells (same cells as in Fig. 1), resurgent current amplitudes were normalized to the peak transient current at $0 \mathrm{mV}$ and plotted as a percentage of resurgent current against voltage (Fig. $2 B$, top). Cells containing the $\beta 4$ peptide indeed had more relative resurgent current than control cells, consistent with an effective block and unblock of $\mathrm{Na}$ channels by the $\beta 4$ peptide (significant main effect; $F_{(2,35)}=8.3$; $p=0.001$; Tukey's post hoc test: $\beta 4$ peptide vs control, $p=0.001$; vs $\beta 4$ protein, $p=0.07$ ). The current was not significantly different in control and $\beta 4$-expressing cells, however (Tukey's post hoc test, $p=0.2$ ). In contrast, expression of $\beta 4$ increased the persistent current flowing after repolarization (control, $-48 \pm 14 \mathrm{pA}$; $\beta 4$ peptide, $-185 \pm 74 \mathrm{pA} ; \beta 4$ protein, $-131 \pm 24 \mathrm{pA})$. When persistent currents in each cell were normalized to the transient current at $0 \mathrm{mV}$, larger relative currents consistently occurred in the presence of the $\beta 4$ subunit (Fig. $2 B$, bottom) (significant main effect; $F_{(2,35)}=3.5 ; p=0.04$; Tukey's post hoc test: $\beta 4$

$\leftarrow$

were normalized to the peak transient current evoked in each cell at $0 \mathrm{mV}$ and plotted versus voltage. Control, $n=15 ; \beta 4$ peptide, $n=10 ; \beta 4$ protein, $n=13$. Bottom, Mean persistent currents, measured as the mean steady-state current in the last $10 \mathrm{~ms}$ of the repolarizing step. Currents were normalized and plotted as in the top panel. Same cells as in the top panel. C, Top, Voltage protocol (top) and representative control traces (middle) for assaying recovery from inactivation after conditioning at $+60 \mathrm{mV}$. The first step to $0 \mathrm{mV}$ in the voltage protocol is the reference step. Bottom, The conditioning current and first test current at higher gain. Mean peak currents evoked by test steps after a conditioning step to $+60 \mathrm{mV}$, normalized to the peak current evoked by the reference step and plotted versus recovery interval, are shown. Recovery was faster in $\beta 4$ peptide cells $(n=4)$ compared with either control $(n=5)$ or $\beta 4$ protein $(n=$ 5) cells. Error bars indicate SEM. 
protein vs control, $p=0.03 ; \beta 4$ peptide vs control, $p=0.47$ ) Together, these data demonstrate that expression of the fulllength $\beta 4$ subunit with $\mathrm{Na}_{\mathrm{V}} 1.1$ is not sufficient to generate resurgent current in $\mathrm{HEK}-\mathrm{Na}_{\mathrm{V}} 1.1$ cells, consistent with the recent report that $\beta 4$ does not induce a resurgent current in tsA-201 cells expressing $\mathrm{Na}_{\mathrm{V}} 1.2$ (Chen et al., 2008). Instead, like the results obtained with step depolarizations, the results suggest that coexpression of $\beta 4$ with $\mathrm{Na}_{\mathrm{V}} 1.1$ destabilizes inactivated states at voltages between -30 and $+10 \mathrm{mV}$, permitting a higher occupancy of open states than does expression of $\mathrm{Na}_{\mathrm{V}} 1.1$ alone.

At strongly hyperpolarized potentials, however, expression of $\beta 4$ did not modify the transition from inactivated to closed states. Figure $2 C$ illustrates recovery at $-110 \mathrm{mV}$ from inactivation induced by a short step to $+60 \mathrm{mV}$ in control cells, cells containing the $\beta 4$ peptide, and cells expressing the $\beta 4$ protein. Recovery in cells expressing the $\beta 4$ protein was indistinguishable from control (double-exponential fit parameters to mean data from control, $\beta 4$ protein, $\beta 4$ peptide: $\tau_{\text {fast }}=1.4,1.5,1.2 \mathrm{~ms} ; \tau_{\text {slow }}=16.6$, $\left.12.9,9.1 \mathrm{~ms} ; \%_{\text {fast }}=44,42,47 \% ; n=5,5,4\right)$. The similarity of recovery times between the control and the $\beta 4$ protein condition supports the idea that depolarizing steps favor the same fast inactivated states in both cases and that $\beta 4$ reduces the stability of inactivation only at voltages in the vicinity of $0 \mathrm{mV}$. In contrast, channels exposed to the $\beta 4$ peptide recovered more rapidly than in control conditions, consistent with the idea that block by the peptide prevents fast inactivation at positive potentials and permits reopening and deactivation at negative potentials (Raman and Bean, 2001; Grieco et al., 2005).

\section{$\beta 1$ coexpression counteracts the effect of $\beta 4$ on inactivation}

Expression of $\beta 4$ increased persistent sodium current beyond $5 \%$ of the transient sodium current, a value that is considerably greater than anything observed in central neurons, in which persistent currents have been reported to range from 0.7 to $4 \%$ of transient currents (Cummins et al., 1994; Parri and Crunelli, 1998; Magistretti and Alonso, 1999; Maurice et al., 2001; Taddese and Bean, 2002). It therefore seemed likely that, in neurons, other factors might limit the ability of $\beta 4$ to enhance persistent current. Given the widespread expression of $\beta 1$ in the nervous system, we considered the possibility that $\beta 1$, which accelerates inactivation in heterologous expression systems (Isom et al., 1992; Chen and Cannon, 1995), might modify the influence of $\beta 4$. To test this idea, we first transfected $\mathrm{HEK}-\mathrm{Na}_{\mathrm{V}} 1.1$ cells with the $\mathrm{Na}$ channel $\beta 1$ subunit $(n=9)$ and measured currents evoked by $100 \mathrm{~ms}$ step depolarizations (Fig. $3 A$, top). With $\beta 1$ transfection, the amplitudes of persistent currents were similar to control (Fig. 3B, left). As in other heterologous expression systems, $\beta 1$ expression accelerated fast inactivation, reducing the decay time constant at 0 $\mathrm{mV}$ from $0.72 \pm 0.03 \mathrm{~ms}$ in control $(n=26)$ to $0.63 \pm 0.03 \mathrm{~ms}$ $(n=9 ; p=0.005)$ (Fig. $3 C$, left). Thus, $\beta 1$ and $\beta 4$ have contrasting effects on the macroscopic properties of fast inactivation.

This contrast is of interest because it is likely that $\alpha, \beta 1$, and $\beta 4$ subunits assemble to form heterotrimeric channels: biochemical studies indicate that the majority of $\mathrm{Na}$ channel $\alpha$ subunits in the brain associate with one noncovalently linked $\beta$ subunit, such as $\beta 1$, and one covalently linked $\beta$ subunit, such as $\beta 4$ (Reber and Catterall, 1987; Yu et al., 2003). Therefore, to test how $\beta 1$ and $\beta 4$ subunits interact functionally, we transfected $\mathrm{HEK}-\mathrm{Na}_{\mathrm{V}} 1.1$ cells with both $\beta 1$ and $\beta 4$. Coexpression of $\beta 1$ and $\beta 4(n=14)$ produced persistent current amplitudes that overlapped with those of control cells $(n=15)$ or cells transfected with $\beta 1(n=9)$ (Fig. $3 A, B$, right). Moreover, the decay time constant at $0 \mathrm{mV}$ was significantly faster in cells coexpressing $\beta 1$ and $\beta 4$ (Fig. $3 C$, left)
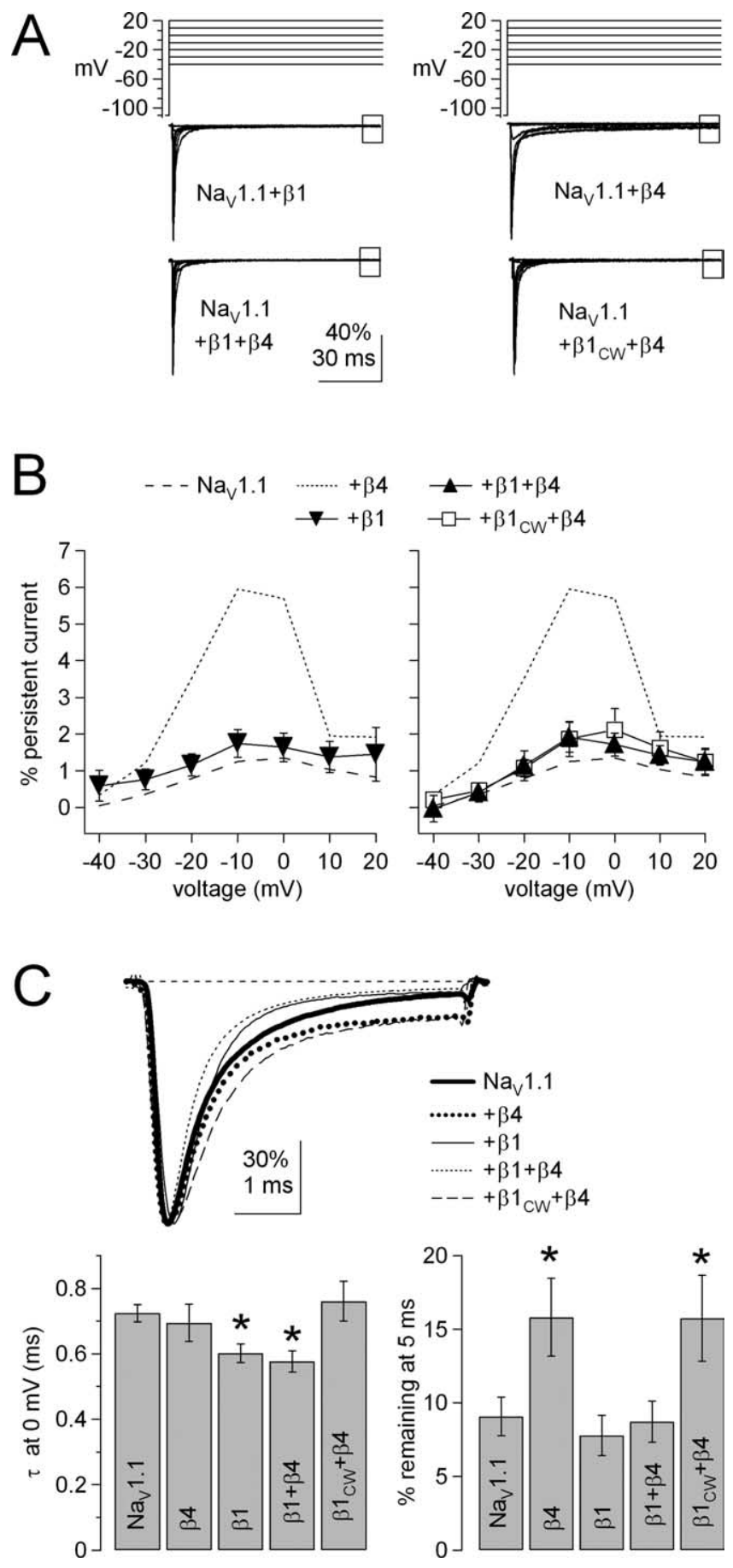

Figure 3. Coexpression of wild-type $\beta 1$ subunit, but not the GEFS + mutant subunit $\beta 1_{\text {c121w }}$, prevents the $\beta 4$-mediated destabilization of inactivation. $A$, Voltage protocol to elicit persistent current and representative traces evoked with $\beta$ subunit transfection as labeled. The box indicates the region of the trace analyzed in $\boldsymbol{B}$. $\boldsymbol{B}$, Persistent currents measured as in Figure $1 C$, plotted versus voltage. Mean persistent currents for control (dashed line) and $\beta 4-$ transfected (dotted line) are replotted for comparison. Left, $\beta 1$-transfected $(n=9)$ cells have small persistent currents, similar to control cells. Right, The increase in persistent current by $\beta 4$ was prevented by coexpression of $\beta 1(n=14)$. Coexpression of $\beta 1_{1121 \mathrm{w}}$ with $\beta 4(n=16)$ prevented the increase in persistent current nearly as well as wild-type $\beta 1$. C, Top, Representative Na currents evoked by a $5 \mathrm{~ms}$ step to $0 \mathrm{mV}$ for five conditions, as labeled. Bottom, Mean time constants from single exponential fits to currents evoked as in $\boldsymbol{A}$ (left bars) and the percentage of current remaining at the end of the $5 \mathrm{~ms}$ step (right bars) are shown for each condition for control cells $(n=26)$ and for cells transfected with $\beta 1(n=9), \beta 4(n=20)$, $\beta 1+\beta 4(n=14)$, and $\beta 4+\beta 1_{C 121 \mathrm{w}}(n=17)$. Asterisks indicate significant differences from control. Error bars indicate SEM. 

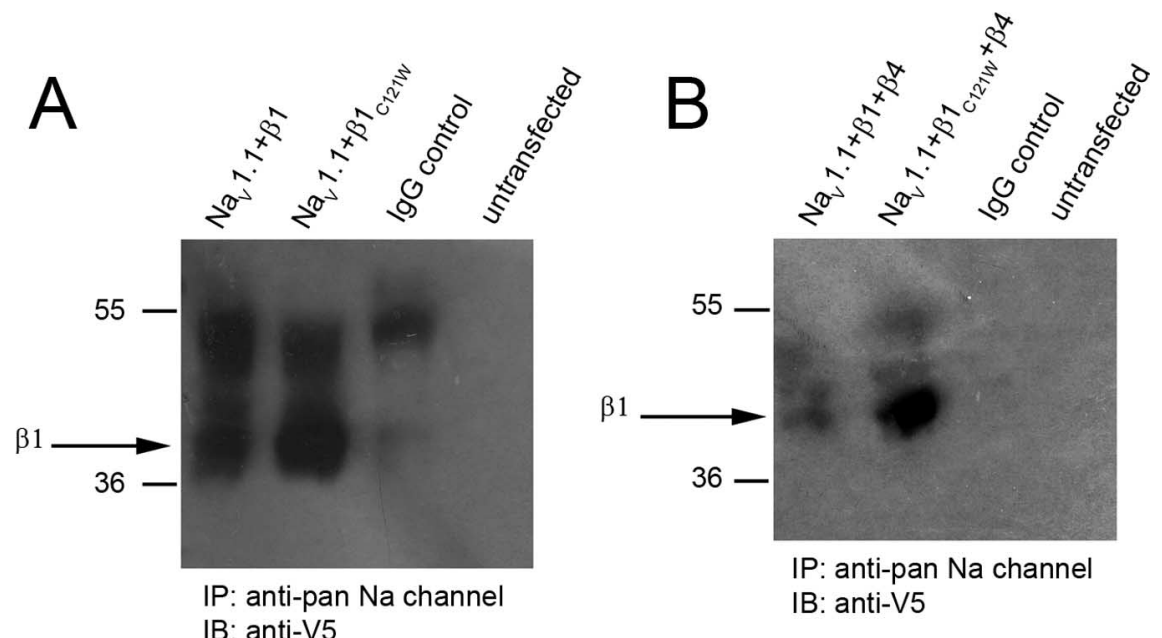

IP: anti-pan Na channe IB: anti-V5
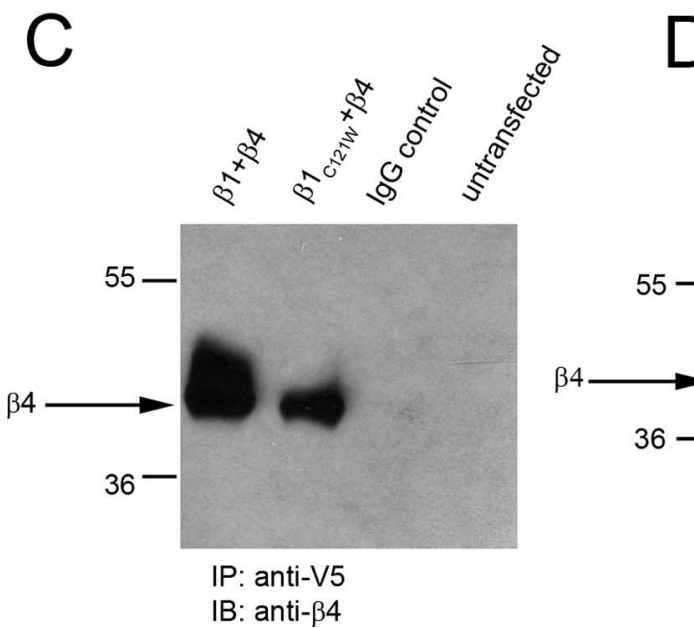

D

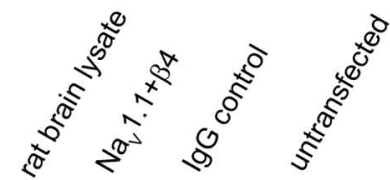

IP: anti-pan Na channel IB: anti-V5

IB: anti- $\beta 4$

Figure 4. Association of $\mathrm{Na}_{\mathrm{v}} 1.1, \beta 1, \beta 1_{\mathrm{C121}}$, and $\beta 4$ subunits. Coimmunoprecipitation experiments of $\mathrm{Na}^{+}$channel $\alpha$ and $\beta$ subunits were performed on transfected HEK-293T cells. All molecular weight standards are indicated in kilodaltons. $A, \mathrm{Na}_{\mathrm{v}} 1.1$ associates with $\beta 1$ and with $\beta 1_{\mathrm{C} 121 \mathrm{w}}$. Cells expressing $\mathrm{Na}_{\mathrm{v}} 1.1+\beta 1-\mathrm{V} 5 \mathrm{or} \mathrm{Na}_{\mathrm{v}} 1.1+\beta 1_{\mathrm{C121}}-\mathrm{V} 5$ were immunoprecipitated with anti-pan $\mathrm{Na}^{+}$channel antibody or rabbit lgG. The immunoblot was probed with anti-V5 antibody to detect $\beta 1-\mathrm{V} 5$ or $\beta 1_{\mathrm{C121}}$ -V5. Immunoreactive $\beta 1$ bands are indicated by the arrow. $\boldsymbol{B}, \mathrm{Na}_{\mathrm{v}} 1.1$ and $\beta 1$ or $\beta 1_{\mathrm{C121w}}$ associate in the presence of $\beta 4$. Cells

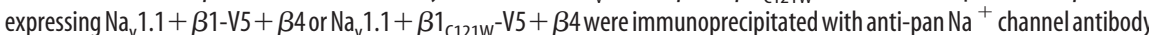
or rabbit lgG. The immunoblot was probed with anti-V5 antibody to detect $\beta 1-\mathrm{V} 5$ or $\beta 1_{\mathrm{C} 121 \mathrm{w}}-\mathrm{V} 5$. Immunoreactive $\beta 1$ bands are indicated by the arrow. $C, \beta 1$ or $\beta 1_{\text {C121w }}$ associates with $\beta 4$ in the absence of $\alpha$ subunits. Cells expressing $\beta 1-V 5+\beta 4$ or $\beta 1_{\mathrm{C} 121 w}-\mathrm{V} 5+\beta 4$ were immunoprecipitated with anti-V5 antibody or mouse $\mathrm{lg}$. The immunoblot was probed with anti- $\beta 4$ antibody. Immunoreactive $\beta 4$ bands are indicated by the arrow. $\boldsymbol{D}$, Association of $\mathrm{Na}_{\mathrm{v}} 1.1$ and $\beta 4$. Cells expressing $\mathrm{Na}_{\mathrm{v}} 1.1+\beta 4$ were immunoprecipitated with anti-pan $\mathrm{Na}^{+}$channel antibody or rabbit lgG. The immunoblot was probed with anti- $\beta 4$ antibody. Immunoreactive $\beta 4$ bands are indicated by the arrow. A lane containing rat brain membranes, prepared as by Brackenbury et al. (2008), is included as a positive control to show $\beta 4$ immunoreactivity. IP, Immunoprecipitation; IB, immunoblot.

( $n=14 ; 0.58 \pm 0.03 \mathrm{~ms} ; p<0.001$ vs control), similar to $\beta 1$ expression alone. These changes indicate that, despite the presence of endogenous $\beta 1 \mathrm{~B}$, expression of $\beta 1$ has a distinct and specific effect on $\beta 4$, namely, to inhibit the $\beta 4$-mediated destabilization of inactivation.

\section{An epilepsy mutation in $S c n 1 b$ decreases the ability of $\beta 1$ to reverse the effects of $\beta 4$}

These results raise the possibility that disruptions of $\beta 1$, such as those that occur in epilepsy and other types of seizure disorders, might alter the regulation of $\beta 4$. Specifically, a mutation of a cysteine to a tryptophan in the $\beta 1$ extracellular domain $\left(\beta 1_{\mathrm{C} 121 \mathrm{~W}}\right)$ leads to GEFS + in humans (Wallace et al., 1998, 2002 ). To test whether this mutation changes the influence of $\beta 1$ on $\beta 4$, we measured Na currents in HEK$\mathrm{Na}_{\mathrm{V}} 1.1$ cells, in which $\beta 1_{\mathrm{C} 121 \mathrm{~W}}$ was coexpressed with $\beta 4$. $\beta 1_{\mathrm{C} 121 \mathrm{~W}}$ prevented the $\beta 4$-induced increase in persistent current as effectively as did $\beta 1$ (at $-10 \mathrm{mV}: \beta 4$ alone, $6.0 \pm 2.0 \% ; \beta 1+\beta 4,1.9 \pm 0.4 \%$; vs $\left.\beta 1_{\mathrm{C} 121 \mathrm{~W}}+\beta 4,1.9 \pm 0.5 \% ; n=13,14,14\right)$ (Fig. $3 A, B$, right). Inspection of the traces, however, indicated that the inactivation time constant was slower when $\beta 4$ was coexpressed with $\beta 1_{\mathrm{C} 121 \mathrm{~W}}$ than with wildtype $\beta 1$, resembling the condition with $\beta 4$ alone $\left(\beta 1_{\mathrm{C} 121 \mathrm{~W}}+\beta 4,0.76 \pm 0.06 \mathrm{~ms}, n=\right.$ 17 ; vs $\beta 1+\beta 4, p=0.01)$. This difference in the rate of entry into inactivated states was even more apparent after examination of the percentage of current remaining at the end of a $5 \mathrm{~ms}$ step. This amplitude, which reflects a slower component of inactivation, was relatively small in control or with $\beta 1$ alone, but relatively large with $\beta 4$ alone (Fig. $3 C$ ). Moreover, when $\beta 4$ was expressed with $\beta 1_{\mathrm{C} 121 \mathrm{~W}}$, the current was nearly twice that with the wild-type $\beta 1$ $\left(\beta 1+\beta 4\right.$ vs $\beta 1_{\mathrm{C} 121 \mathrm{~W}}+\beta 4 ; 8.7 \pm 1.4 \%$ vs $15.7 \pm 2.9 \% ; n=14,17 ; p=0.04)$. Thus, the GEFS + mutation makes the $\beta 1$ subunit less effective in counteracting the destabilization of inactivation by $\beta 4$, raising the possibility that a prolongation of $\mathrm{Na}$ currents contributes to the alteration of neuronal firing patterns in carriers of this mutation.

$\beta 1$ subunits might exert their effects on persistent current either by preventing $\beta 4$ from associating with $\alpha$ subunits and/or by having a dominant influence on channel gating. To test the likelihood that $\mathrm{Na}_{\mathrm{V}} 1.1, \beta 1$, and $\beta 4$ form functional heterotrimeric complexes, we transfected HEK-293T cells with different combinations of subunits and assessed their association by coimmunoprecipitation. Cotransfection of $\mathrm{Na}_{\mathrm{V}} 1.1$ with $\mathrm{V} 5$-tagged $\beta 1$ indicated that these subunits associated (Fig. 4A) and that this association persisted but was weakened when $\beta 4$ was also present (Fig. 4B). Transfection of cells with only $\beta 1$ and $\beta 4$ revealed a strong interaction between these two subunits even in the absence of $\mathrm{Na}_{\mathrm{V}} 1.1$ (Fig. 4 C), suggesting that one action of $\beta 1$ may indeed be to sequester $\beta 4$ and limit its association with $\alpha$ subunits. If so, the macroscopic electrophysiological properties measured in HEK$\mathrm{Na}_{\mathrm{V}} 1.1$ cells transfected with both $\beta$ subunits may result in part from $\mathrm{Na}_{\mathrm{V}} 1.1$ monomers, thus mimicking the control condition. $\beta 4$, however, interacted strongly with $\mathrm{Na}_{\mathrm{V}} 1.1$ alone (Fig. $4 D$ ), suggesting that any free $\beta 4$ would be likely to enter a channel complex. Because the macroscopic currents in cells expressing the three subunits mimic neither the control condition nor the condition with a single $\beta$ subunit, it seems likely that a nonnegligible subset of channels contain $\mathrm{Na}_{\mathrm{V}} 1.1, \beta 1$, and $\beta 4$ and that these heterotrimers contribute to the overall electrophysiological phenotype. Consistent with this idea, with all three subunits 
present, an interaction of $\beta 4$ with $\mathrm{Na}_{\mathrm{V}} 1.1$ was evident (data not shown).

Next, we repeated these experiments with $\beta 1_{\mathrm{C} 121 \mathrm{~W}}$ substituted for the wild-type $\beta 1$ subunit. The mutant subunit associated with $\mathrm{Na}_{\mathrm{V}} 1.1$ and, in contrast to wild-type $\beta 1$, this association remained strong in the presence of $\beta 4$ (Fig. $4 A, B$ ). Conversely, the association of $\beta 1_{\mathrm{C} 121 \mathrm{~W}}$ and $\beta 4$ in the absence of the $\alpha$ subunit appeared less robust than with wild-type $\beta 1$. This result suggests that the $\beta 1-\beta 4$ interaction is mediated by the extracellular Ig domains (Fig. 4C) and is consistent with previous results showing that $\beta 1_{\mathrm{C} 121 \mathrm{~W}}$ does not function as a cell adhesion molecule (Meadows et al., 2002). Considered in the context of the electrophysiological experiments, which demonstrated reduced persistent current but slowed inactivation rates relative to control, these results support the idea that heterotrimeric channels comprising $\alpha, \beta 1_{\mathrm{C} 121 \mathrm{~W}}$, and $\beta 4$ do indeed assemble and suggest that wild-type $\beta 1$ need not prevent $\beta 4$ association with the $\alpha$ subunit to oppose the effects of $\beta 4$ on gating.

\section{The extracellular domain of $\beta 1$ regulates persistent current} Because the $\mathrm{C} 121 \mathrm{~W}$ mutation is in the extracellular domain, these data suggested that this region of $\beta 1$ is necessary for the normal regulation of inactivation. We therefore tested whether the suppression of persistent current and promotion of inactivation could be achieved without the intracellular domain of $\beta 1$ by expressing a " $\beta 1 / 4$ " chimeric subunit, which consisted of the extracellular and the transmembrane domains of $\beta 1$ and the intracellular domain of $\beta 4$. In cells expressing $\beta 1 / 4(n=7)$, both the persistent current amplitudes and the time course of inactivation were indistinguishable from $\beta 1$-expressing cells (Fig. $5 A$, top left, $B$ ). The simplest interpretation of these results is that the wild-type extracellular domain directly modulates the stability of inactivation. The extracellular domain, however, also contains sites required for interactions with the $\alpha$ subunit, thereby determining the position of $\beta$ subunits in the channel complex (McCormick et al., 1998). Because the sites of $\alpha-\beta$ interaction are likely to differ for $\beta 1$ and $\beta 4$, an alternative interpretation is that the $\beta 1 / 4$ chimera inhibits the channel openings that are favored by $\beta 4$ simply by wrongly positioning the $\beta 4$ intracellular domain.

To address this possibility, we coexpressed $\beta 1 / 4$ and $\beta 4$. With both subunits present, heterotrimeric channels are predicted to have two $\beta 4$ intracellular domains, one in the site normally occupied by the $\beta 1$ cytoplasmic tail and one in the normal position for $\beta 4$. Under these conditions, the persistent current remained at control levels and was indistinguishable from coexpression of $\beta 1+\beta 4(n=11)$ (Fig. 5A, bottom). These results support the idea that the extracellular domain of $\beta 1$ primarily governs persistent current in $\mathrm{Na}_{\mathrm{V}} 1.1$, as it does with other $\alpha$ subunits (Chen and Cannon, 1995; McCormick et al., 1998, 1999). The slow phase of inactivation, reflected by the percentage of current remaining at 5 $\mathrm{ms}$, was also restored to control levels, as it was with $\beta 1+\beta 4$. The fast inactivation time constant was not consistently reduced to levels achieved by expression of $\beta 1+\beta 4$ (Fig. $5 B$ ), however, leaving the possibility open that intracellular domains also contribute to the regulation of inactivation (Spampanato et al., 2004).

Next, we tested whether the $\beta 2$ subunit, which resembles $\beta 4$ both in sequence similarity and in its disulfide linkage to $\mathrm{Na}$ channel $\alpha$ subunits (Yu et al., 2003), might also resemble $\beta 4$ in its influence on $\mathrm{Na}$ current. Indeed, expression of $\beta 2$ in HEK$\mathrm{Na}_{\mathrm{V}} 1.1$ cells increased persistent current amplitudes $(n=12)$, although to a lesser extent than $\beta 4$ (Fig. $5 A$, top right). Expression of $\beta 2$ also increased the percentage of current remaining at $5 \mathrm{~ms}$, while leaving the inactivation rate unaffected relative to control
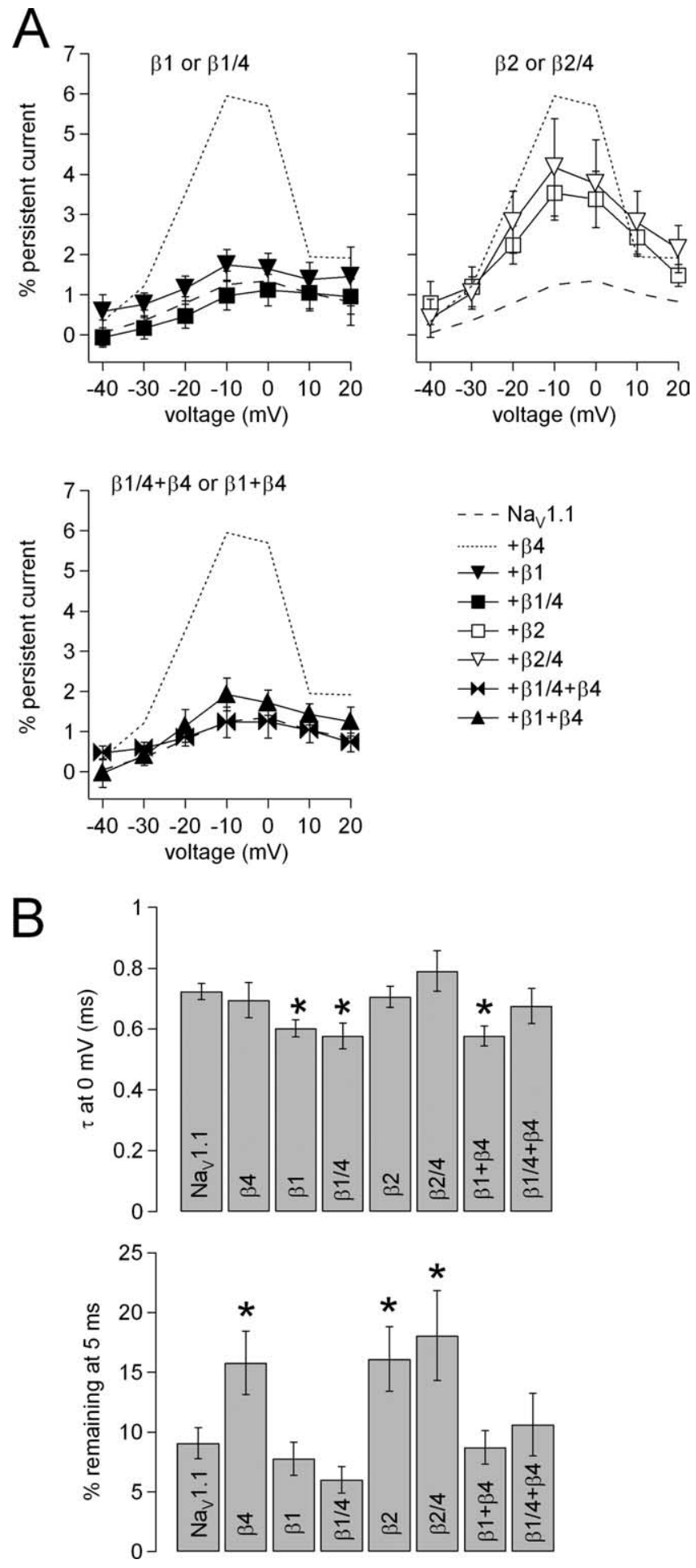

Figure 5. Chimeric $\beta$ subunits suggest that the extracellular domain regulates persistent current amplitude. $\boldsymbol{A}$, Persistent currents measured as in Figure $1 C$, plotted versus voltage. Mean persistent currents for control (dashed line) and $\beta 4$ transfected (dotted line) are replotted for comparison. The percentage of persistent current is plotted versus voltage for $\mathrm{Na}_{\mathrm{v}} 1.1$ with expression of the following subunits: top left, either $\beta 1(n=9)$ or the $\beta 1 / 4$ chimera $(n=7)$; top right, either $\beta 2(n=12)$ or the $\beta 2 / 4$ chimera $(n=9)$; bottom left, $\beta 1+\beta 4(n=14)$ or $\beta 1 / 4+\beta 4$ ( $n=11)$. $B$, Time constants from single exponential fits to the decay of transient current at $0 \mathrm{mV}$ (top) and the percentage of current remaining at the end of the $5 \mathrm{~ms}$ step (bottom) as in Figure 3 ( for cells transfected with $\beta 1 / 4(n=7), \beta 2(n=12), \beta 2 / 4(n=9)$, and $\beta 1 / 4+\beta 4(n=11)$. Relevant data for control, $\beta 1, \beta 4$, and $\beta 1+\beta 4$ are included for comparison. Asterisks indicate significant differences from control. Error bars indicate SEM. 

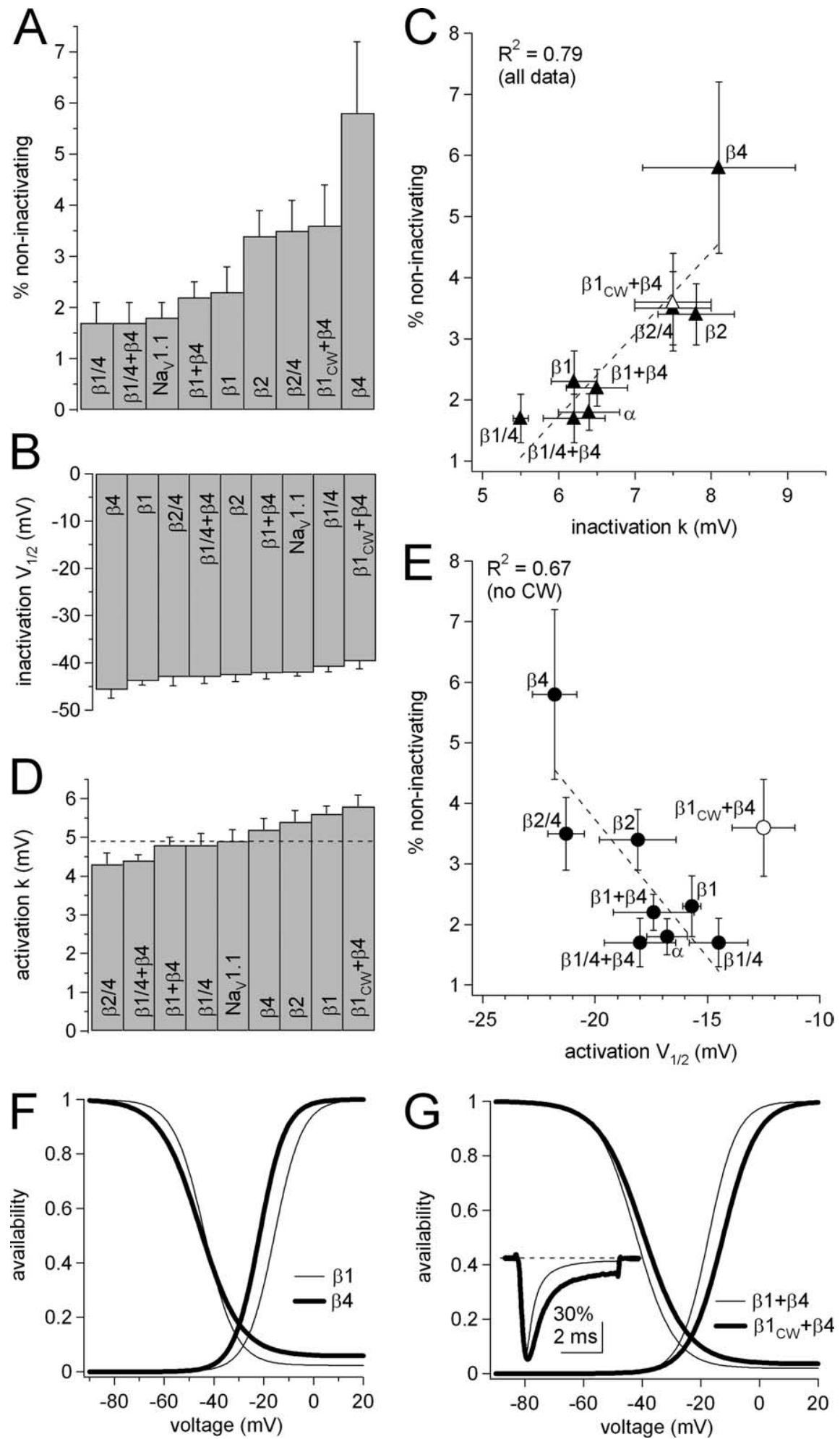

Figure 6. Changes in activation and inactivation parameters increase the window current in HEK-Na 1 1.1-expressing $\beta 4$ and $\beta 2$ but not $\beta 1$. $A$, Inactivation parameters were estimated as in Figure $1 B$, and the noninactivating component is shown for all conditions, as labeled. The $n$ values are as in Figures 3 and 4. $B, V_{1 / 2}$ of inactivation for all conditions; it was not correlated with the percentage of noninactivating current $\left(R^{2}=0.06\right)$. C , The noninactivating component versus the inactivation slope factor, for all conditions, as labeled. The dashed line is the linear fit to the data, with $R^{2}=0.79 . D$, Activation parameters were estimated as in Figure $1 A$, and the activation $k$ is shown for all conditions, as labeled. The $n$ values are as follows: $\operatorname{control}(\alpha), 15 ; \beta 4,13 ; \beta 2 / 4,9 ; \beta 2,11 ; \beta 1 / 4,5 ; \beta 1+\beta 4,13 ; \beta 1,9$, $\beta 1_{\mathrm{c}}+\beta 4,13 ; \beta 1 / 4+\beta 4,11$. Activation $k$ did not correlate with the percentage of noninactivating current $\left(R^{2}=0.11\right)$. $E$, The noninactivating component of the availability curve versus the activation $V_{1 / 2}$. The dashed line is the linear fit to the data, with the point corresponding to $\beta 1_{\mathrm{c121 \textrm {w }}}+\beta 4$ (open symbol) excluded. $R^{2}=0.67 . \boldsymbol{F}$, Conductance and availability curves with the mean activation and inactivation parameters for $\beta 1$ (thin line) and $\beta 4$ (thick line) in HEK-Nav1.1 cells, illustrating the larger window and noninactivating current with $\beta 4$ relative to $\beta 1$. $\mathbf{G}$, Conductance and availability curves as in $\boldsymbol{F}$ for $\beta 1+\beta 4$ and $\beta 1_{\mathrm{cW}}+\beta 4$. The inset illustrates the difference in the time course of inactivation between $\beta 1+\beta 4$ and $\beta 1_{\mathrm{C121w}}+\beta 4$ (same traces as in Fig. 30). Error bars indicate SEM.
(Fig. $5 B$ ). A $\beta 2 / 4$ chimera $(n=9)$, composed of the extracellular and the transmembrane domains of $\beta 2$ and the intracellular domain of $\beta 4$, behaved in much the same way as $\beta 2$ and $\beta 4$ (Fig. $5 A$, top right, $B$ ). These data indicate that $\beta 2, \beta 4$, and $\beta 2 / 4$, the extracellular domains of which are expected to bind in a similar way to the $\alpha$ subunit, influence inactivation in a qualitatively similar manner.

Together, the data indicate that persistent current amplitudes, as well as the percentage of current remaining at $5 \mathrm{~ms}$, can be either relatively large (occurring with $\beta 4, \beta 2$, or $\beta 2 / 4$ ) or relatively small (occurring with $\beta 1, \beta 1 / 4, \beta 1+\beta 4$, or $\beta 1 / 4+\beta 4$, as well as with $\mathrm{Na}_{\mathrm{V}} 1.1$ alone). For convenience (with no mechanistic implication), the former group will be referred to as the "disulfide-linked" group, and the latter (excluding the control) will be referred to as the "wild-type $\beta 1_{\text {extra }}$ " group. The $\beta 1_{\mathrm{C} 121 \mathrm{~W}}+\beta 4$ condition presents an anomaly that will be considered separately.

\section{$\boldsymbol{\beta}$ subunits affect both window current and the percentage of noninactivating current}

To explore the basis for the differences in persistent current between the disulfidelinked and wild-type $\beta 1_{\text {extra }}$ groups, we examined the activation and inactivation curves. These allow an estimation of the size of the window current between the curves, as well as the percentage of current that does not inactivate even at the most depolarized potentials. We began by analyzing the availability curves recorded in all conditions. As in Figure 1, data from each cell were fitted with Boltzmann functions to obtain values of $V_{1 / 2}, k$, and percentage of noninactivating current. The mean values for the noninactivating current fell into two groups. The wild-type $\beta 1_{\text {extra }}$ group and control cells had $<2.3 \%$ current, whereas the disulfide-linked group and $\beta 1_{\mathrm{C} 121 \mathrm{~W}}+\beta 4$ had $>3.4 \%$ current (Fig. 6A). These data suggest that the disulfide-linked subunits actively increase the equilibrium occupancy of the open state, whereas the subunits with the wildtype $\beta 1$ extracellular domain counteract this effect. With the exception of $\beta 1_{\mathrm{C} 121 \mathrm{~W}}+\beta 4$, this grouping parallels the amplitudes of persistent currents measured at negative voltages.

Next, we tested whether $\beta$ subunits expressed in $\mathrm{HEK}-\mathrm{Na}_{\mathrm{V}} 1.1$ cells modified the window current. In general, the window current may be increased by a negative shift in the activation curve, a positive shift in the inactivation curve, and/or a flattening of the slope of either curve. As shown 
in Figure $6 B$, the $V_{1 / 2}$ of inactivation was relatively insensitive to $\beta$ subunit expression. In nearly all conditions, the mean $V_{1 / 2}$ fell between -41 and $-44 \mathrm{mV}$. The value for $\beta 4$ alone was slightly negative to this range $(-45.7 \pm 1.7 \mathrm{mV})$ and for $\beta 1_{\mathrm{C} 121 \mathrm{~W}}+\beta 4$ was slightly positive to this range $(-39.7 \pm 1.6 \mathrm{mV})$. The slope factor of the curve, $k$, however, was indeed affected by the different $\beta$ subunits. The four conditions with more noninactivating current had shallower slopes, with $k$ values $\geq 7.5 \mathrm{mV}$ (disulfide linked and $\beta 1_{\mathrm{C} 121 \mathrm{~W}}+\beta 4$ ), whereas the five conditions with less noninactivating current had steeper slopes, with $k$ values $\leq 6.5$ $\mathrm{mV}$ (wild-type $\beta 1_{\text {extra }}$ and control) (Fig. 6C). Consequently, the inactivation $k$ was correlated with the noninactivating current $\left(R^{2}=0.79\right)$. Because the inactivation $V_{1 / 2}$ is relatively constant across conditions, shallower slopes widen the voltage range over which window current can flow. For instance, with a $V_{1 / 2}$ of -42 $\mathrm{mV}$, shifting the slope factor from $6.25 \mathrm{mV}$ to $7.5 \mathrm{mV}$ doubles the availability at $-15 \mathrm{mV}$. The overlay of availability curves with the mean fit parameters of $\beta 1$ and $\beta 4$ illustrates this effect (Fig. $6 F$ ). These data therefore suggest that persistent current across a range of potentials may be promoted in the disulfide-linked subunits by both a weaker voltage sensitivity of inactivation and a greater equilibrium stability of the open state.

Across conditions, the complement of $\beta$ subunits affected the parameters of activation as well. The slope factors covered a relatively wide range of values but were not correlated with the amount of noninactivating current $\left(R^{2}=0.11\right)$ (Fig. $\left.6 D\right)$. The steepest slopes occurred with the chimeras $(\beta 2 / 4, \beta 1 / 4)$ and the coexpressed subunits $(\beta 1+\beta 4, \beta 1 / 4+\beta 4)$, suggesting that, at least in some contexts, the intracellular domain of $\beta 4$ makes channel opening more sensitive to voltage. This effect is particularly noticeable when $\beta 1$ is compared with $\beta 1 / 4(p=0.07)$ or $\beta 2$ is compared with $\beta 2 / 4$ ( $p=0.02$ ). An exception, however, is the moderate $k$ value of $\beta 4$ alone $(5.2 \pm 0.3)$, indicating that the effects of the intracellular and extracellular domains are not altogether independent of their context in a full protein. Excluding the data for $\beta 1_{\mathrm{C} 121 \mathrm{~W}}+\beta 4$, the $V_{1 / 2}$ for activation was negatively correlated with the percentage of noninactivating current $\left(R^{2}=\right.$ $0.67)$ (Fig. $6 E)$. The $V_{1 / 2}$ value was most negative for $\beta 4(-21.8$ $\mathrm{mV})$. Also, when $\beta 4$ was coexpressed with either $\beta 1$ or $\beta 1 / 4$, the $V_{1 / 2}$ tended to shift negative relative to the value for $\beta 1$ or $\beta 1 / 4$ alone. A hyperpolarization of $V_{1 / 2}$ also occurred when the $\beta 4$ tail was added to $\beta 2$ to make the $\beta 2 / 4$ chimera. Thus, expressing the $\beta 4$ intracellular domain positioned correctly (i.e., on a disulfidelinked subunit) promoted channel opening at more negative potentials. The resulting shift in the activation curve is expected to expand the window in which persistent current can flow (Fig. $6 F$ ).

Coexpressing $\beta 1_{\mathrm{C} 121 \mathrm{~W}}$ and $\beta 4$ provided an exception to the generalizations that pertained to the other subunits. $\beta 1_{\mathrm{C} 121 \mathrm{~W}}$ and $\beta 4$ generated channel complexes that resembled the disulfidelinked group in their large noninactivating components and shallow slope of the availability curves, as well as in their largepercentage current remaining after $5 \mathrm{~ms}$. Nevertheless, they generated small persistent currents, as did the wild-type $\beta 1_{\text {extra }}$ group. The activation parameters, however, offered a likely explanation for the peculiarities of the mutant subunit. The activation curves had properties at the extreme of the distribution, with the largest $k$ (5.8) and most positive $V_{1 / 2}(-12.5 \mathrm{mV})$. The depolarizing shift and flattening of the activation curve are expected to diminish persistent current by narrowing the window in which it flows (Fig. $6 \mathrm{G}$ ). Thus, in $\mathrm{HEK}-\mathrm{Na}_{\mathrm{V}} 1.1$ cells, the GEFS + mutation in $\beta 1$ makes it even more effective than the wild-type subunit at stabilizing closed over open states, such that larger depolarizations are necessary to open the channel. At voltages positive enough to activate the channels, however, the mutation renders the $\beta 1_{\mathrm{C} 121 \mathrm{~W}}$ subunit unable to counteract the $\beta 4$-induced favoring of open over inactivated states (Fig. 6G).

Together, these data suggest the following. First, expression of wild-type $\beta 1$ favors inactivated states, and this effect is dominated but not wholly controlled by the extracellular domain. Second, expression of $\beta 4$ favors open states, and this effect is dominated but not wholly controlled by the intracellular domain. Third, expression of the $\beta 1$ GEFS + mutant with $\beta 4$ generally weakens the overall voltage sensitivity of gating, so that channels remain closed rather than open at moderately negative voltages and they remain open rather than inactivated at more positive voltages.

\section{Na currents in neurons made to overexpress $\beta 4$}

The results in $\mathrm{HEK}-\mathrm{Na}_{\mathrm{V}} 1.1$ cells raise the question of which effects of $\beta$ subunits are evident in neuronal environments, where $\mathrm{Na}$ channel gating is also influenced by factors such as additional associated proteins and posttranslational modifications. To address this issue, we overexpressed the $\beta 4$ protein in cultured pyramidal neurons from the CA3 region of the hippocampus (Fig. $7 A$ ). We selected these neurons because they normally lack $\beta 4$ (Yu et al. 2003) but express high levels of $\beta 1$ and $\beta 2$. They also express $\beta 3$, which, like $\beta 1$, binds noncovalently to $\alpha$ subunits (Oh et al., 1994; Morgan et al., 2000; Whitaker et al., 2000). Na channels in CA3 neurons are therefore expected to comprise $\alpha$ subunits $\left(\mathrm{Na}_{\mathrm{V}} 1.1, \mathrm{Na}_{\mathrm{V}} 1.2\right.$, or $\left.\mathrm{Na}_{\mathrm{V}} 1.6\right)$ with $\beta 1+\beta 2$ or $\beta 3+\beta 2$, and these heterotrimers likely interact with other neuronal proteins. We reasoned that transfection of neurons with $\beta 4$ might allow some fraction of channels to incorporate $\beta 4$ instead of $\beta 2$ and/or generate a subset of channels that exist as $\alpha+\beta 4$ heterodimers.

Because the complex morphology of cultured neurons made space clamp of transient currents difficult at the foot of the activation curve, we restricted our analysis to transient currents at 0 $\mathrm{mV}$, where conductance is maximal and less affected by voltage escape, and to small, slow currents evoked by repolarization, where voltage clamp is optimal. We first assayed steady-state inactivation after $100 \mathrm{~ms}$ conditioning steps in control and transfected neurons (Fig. 7A). Expression of $\beta 4$ produced small changes in the $V_{1 / 2}$ of inactivation and steady-state components of the availability curve (Fig. $7 B$ ). The $V_{1 / 2}$ was $-51.8 \pm 2.1 \mathrm{mV}$ in control neurons $(n=5)$ and $-57.6 \pm 1.4 \mathrm{mV}$ with expression of $\beta 4(n=5 ; p=0.12)$, whereas the noninactivating component was $1.0 \pm 0.2 \%$ in control neurons and $1.9 \pm 0.3 \%$ with $\beta 4$ ( $p=$ $0.15)$. Although neither change was statistically significant, the tendency for a negative shift in inactivation and an increase in the noninactivating component resembles the changes seen with transfection of only $\beta 4$ into $\mathrm{HEK}-\mathrm{Na}_{\mathrm{V}} 1.1$ cells. Furthermore, expression of $\beta 4$ produced a significant change in the slope factor, which was $5.0 \pm 0.3 \mathrm{mV}$ in control and became $6.1 \pm 0.2 \mathrm{mV}$ with transfection of $\beta 4$ ( $p=0.025$ ) (Fig. $7 B$ ). Again, the decrease in the steepness of the inactivation curve resembles the effects obtained with transfection of $\beta 4$ alone into $\mathrm{HEK}-\mathrm{Na}_{\mathrm{V}} 1.1$ cells.

Next, to measure persistent and (if any) resurgent current, cells were held at $-90 \mathrm{mV}$, and a step depolarization to $+30 \mathrm{mV}$ was applied, followed by a repolarizing step to $-30 \mathrm{mV}$. Currents were measured relative to the transient current amplitude at 0 $\mathrm{mV}$ (Fig. 7C). Control neurons showed little, if any, resurgent current, and expression of $\beta 4$ did not generate a larger resurgent component (control, $\beta 4: 0.9 \pm 0.2 \%, 1.1 \pm 0.2 \% ; p=0.53 ; n=$ $14,16)$. Persistent currents were also small in all neurons but were consistently larger in $\beta 4$-overexpressing neurons, doubling from $1.1 \pm 0.2 \%$ in control to $2.2 \pm 0.6 \%$ with $\beta 4$. The cumulative 

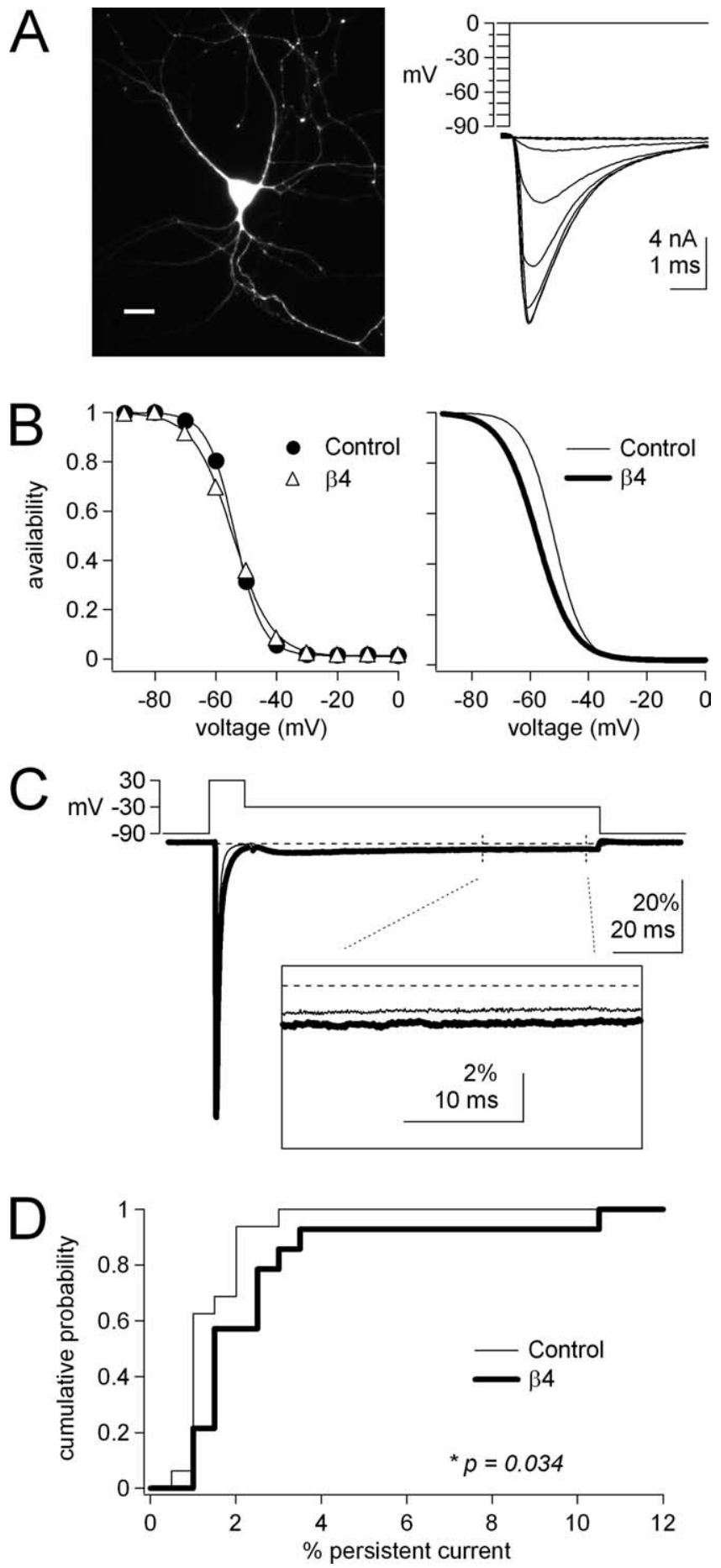

Figure 7. Overexpression of $\beta 4$ produces a small but consistent increase in persistent current in cultured CA3 hippocampal neurons. $\boldsymbol{A}$, Left, Cultured CA3 neuron transfected with GFP. Scale bar, $25 \mu \mathrm{m}$. Right, Voltage protocol to generate steady-state availability curves and representative $N$ a currents elicited in a $\beta 4$-transfected neuron. $\boldsymbol{B}$, Left, Single availability curves from a control and a $\beta 4$-transfected neuron. Parameters of fits for control and $\beta 4$ are as follows: $V_{1 / 2},-53.7,-54.5 ; k, 4.5,6.4$; percentage noninactivating, 1.3, 0.9. Right, Boltzmann curves with the mean parameters for control and $\beta 4$-transfected cells. $\boldsymbol{C}$, Voltage protocol to evoke resurgent and persistent current and representative responses from a control neuron (thin trace) and a $\beta 4$-transfected neuron (thick trace). Currents are normalized to the peak transient current evoked in each cell at $0 \mathrm{mV}$. The inset shows the persistent current at a higher gain. $\boldsymbol{D}$, Cumulative probability plot of the persistent current amplitude in control $(n=14)$ and $\beta 4$ transfected ( $n=16$ ) cells. The $y$ value indicates the probability of finding a cell in which the persistent current is less than or equal to the $x$ value. The distribution was significantly shifted to larger persistent currents in $\beta 4$-transfected cells. probability plot illustrates that the expression of $\beta 4$ increased the likelihood of a larger persistent component (Fig. 7D) (MannWhitney $U$ test; $Z=-2.12 ; p=0.034)$. Like the change in the availability curve, the change in persistent current resembles the changes observed when $\mathrm{HEK}-\mathrm{Na}_{\mathrm{V}} 1.1$ cells were transfected with $\beta 4$ alone. It is therefore possible that transfection of CA3 cells led to the assembly of $\alpha+\beta 4$ heterodimers. Alternatively, because $\beta 3$ subunits have been implicated in increasing persistent currents in expression systems (Qu et al., 2001), it may be that $\alpha+\beta 3+\beta 4$ channels were also formed and that $\beta 3$, unlike $\beta 1$, permits $\beta 4$ mediated destabilization of inactivation.

\section{Na currents in neurons expressing $\beta 4$ but lacking $\beta 1$ and/or $\boldsymbol{\beta 2}$}

The changes in Na currents were smaller in hippocampal neurons than in the HEK-Na 1.1 cells. These differences may result from a population of channel complexes that failed to incorporate $\beta 4$, the expression of other proteins that modulate the effects of $\beta 4$, and/or the antagonism of $\beta 4$ effects by endogenous $\beta 1$. To explore how the removal of $\beta 1$ affects channels that normally include $\beta 4$, we recorded from neurons acutely isolated from $S c n 1 b$ $(\beta 1)$ null and $S c n 1 b / S c n 2 b(\beta 1 / \beta 2)$ double null mice as well as from littermate wild-type or $S c n 2 b$ null controls. For these experiments, we selected cerebellar Purkinje neurons, which normally express high levels of $\beta 4$, as well as $\beta 1$ and $\beta 2$ (Yu et al., 2003), but lack $\beta 3$ (Morgan et al., 2000). A complicating factor in these experiments is the variety of proteins, in addition to $\beta$ subunits, that are known to modulate Na channels in real neurons (Abriel and Kass, 2005). These include GTP-binding protein $\beta \gamma$ subunits (Ma et al., 1997; Mantegazza et al., 2005; Kahlig et al., 2006), calmodulin (Mori et al., 2000; Deschênes et al., 2002; Herzog et al., 2003; Kim et al., 2004; Young and Caldwell, 2005), FGFhomologous factor (Wittmack et al. 2004; Lou et al. 2005), and the endogenous blocking protein of Purkinje cells (Grieco et al., 2005). Nevertheless, we reasoned that comparing the Na currents in the wild-type and null mice might indicate whether the influence of $\beta 1$ that was present in $\mathrm{HEK}-\mathrm{Na}_{\mathrm{V}} 1.1$ cells might also be evident in Purkinje neurons.

We began by measuring activation curves and comparing parameters of the Boltzmann fits (Fig. 8A). Wild-type and Scn $1 b$ null mice showed no significant differences in the $V_{1 / 2}$ or $k$ of activation (control vs Scn $1 b$ null: $V_{1 / 2}=-31.9 \pm 1.0$ vs $-34.0 \pm$ $1.4 \mathrm{mV}, p=0.62 ; k=5.7 \pm 0.3$ vs $6.0 \pm 0.4 \mathrm{mV}, p=0.3 ; n=8$, $6)$. The $k$ values were also statistically indistinguishable in the Scn $2 b$ nulls and the double nulls $(6.1 \pm 0.2$ vs $6.2 \pm 0.3 \mathrm{mV} ; p=$ $0.9 ; n=9,19)$. In the double nulls, however, activation was shifted significantly negative (from $-32.3 \pm 1.2$ to $-36.1 \pm 1.3$ $\mathrm{mV} ; p=0.045)$. Considering the observation that cells that normally lack $\beta 3$ do not upregulate $\beta 3$ after loss of $\beta 1$ (LopezSantiago et al., 2007), the Scn $1 b$ nulls should reveal the properties of $\alpha+\beta 2$ and $\alpha+\beta 4$ channels, and the double nulls should isolate the properties of $\alpha+\beta 4$ channels. The minor negative shift in the former and the significant negative shift in the latter illustrate that cells in which $\beta 4$ is the only available $\beta$ subunit activate more readily in widely differing contexts, from HEK cells to neurons.

Next, we compared inactivation in the presence and absence of $\beta 1$. Scn $1 b$ null Purkinje cells showed a small but significant negative shift in the $V_{1 / 2}$ of the availability curve, from $-65.1 \pm$ $1.0 \mathrm{mV}$ (wild type) to $-68.9 \pm 1.0 \mathrm{mV}$ (Scn1 $1 b$ null; $p=0.02$ ) and no effect on $k$ or the percentage of noninactivating current (wild type: $n=9, k=6.1 \pm 0.2$; $\operatorname{Scn} 1 b$ null: $n=7, k=5.8 \pm 0.1 ; p=$ 0.3 ; percentage noninactivating: wild type, $0.71 \pm 0.18$; Scn $1 b$ null, $0.63 \pm 0.14 ; p=0.7$ ) (Fig. $8 B$ ). Larger changes were evident 

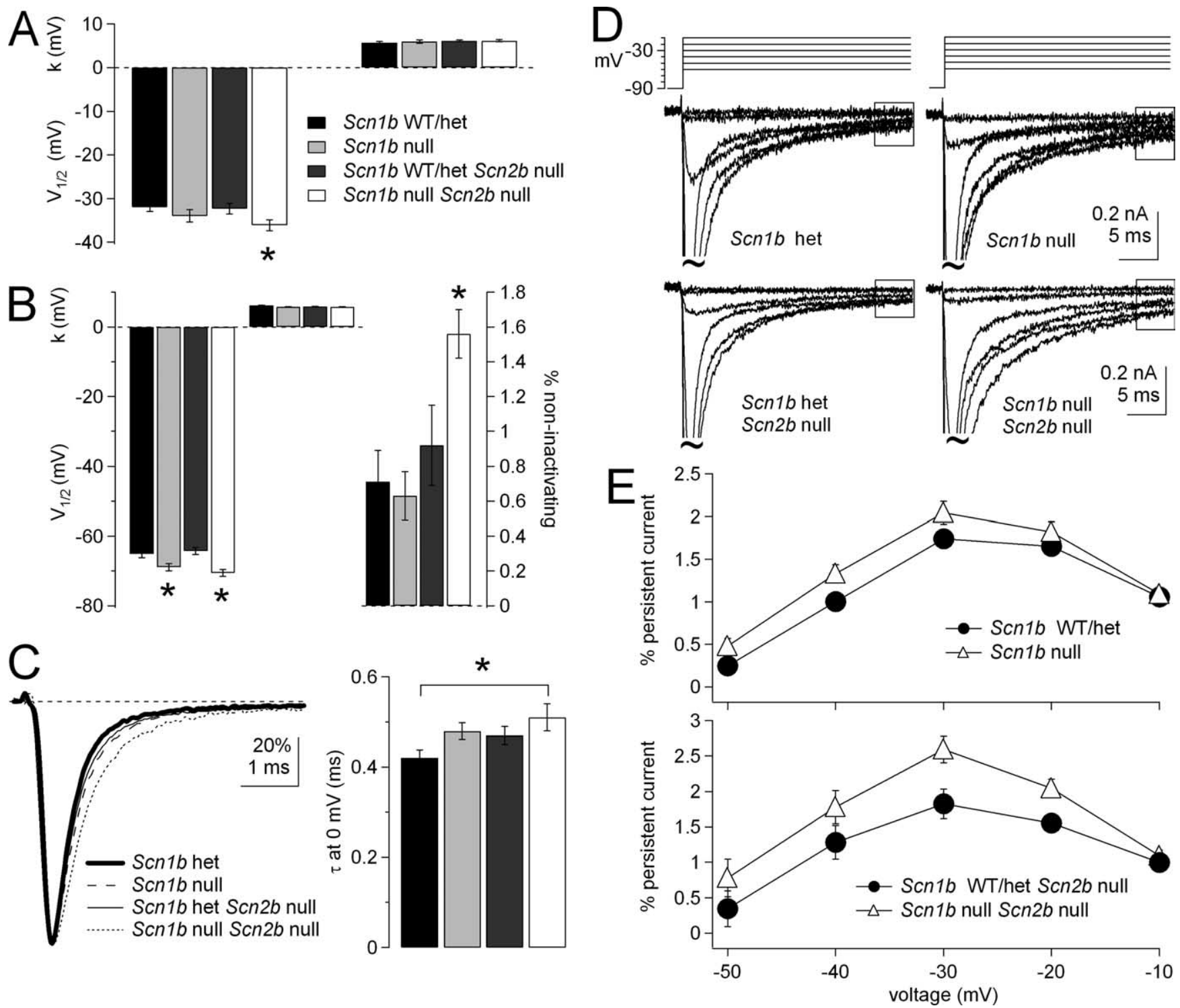

Figure 8. Early persistent currents are increased in $S c n 1 b$ null and $\operatorname{Sen} 1 b \operatorname{Scn} 2 b$ double-null Purkinje neurons. A, Activation parameters were obtained and plotted as in Figure $1 A$ for Purkinje neurons from $S c n 1 b$ and $S c n 2 b$ wild-type, heterozygous, or null mice, as labeled. The $n$ values are as follows: $S c n 1 b$ wild type and heterozygous, $8 ; S c n 1 b$ nulls, 6; $S c n 2 b$ nulls, $9 ;$ double nulls, 19 . Asterisks indicate significant differences relative to littermate controls. $\boldsymbol{B}$, Inactivation parameters were obtained and plotted as in Figure $1 B$. C, Left, Representative transient currents evoked by a voltage step to $0 \mathrm{mV}$ for the four conditions. Right, Mean time constants from single exponential fits to current decays at $0 \mathrm{mV}$. $\boldsymbol{D}$, Voltage protocols and representative Na currents from Purkinje cells isolated from a Scn $1 b$ heterozygous, Scn $1 b$ null, Scn $1 b$ heterozygous Scn $2 b$ null, and Scn $1 b \operatorname{Scn} 2 b$ double-null mouse, as labeled. $\boldsymbol{E}$, The mean early persistent current from the last $5 \mathrm{~ms}$ of a $30 \mathrm{~ms}$ step (boxed area in $\boldsymbol{D}$ ), normalized to the peak transient current at $0 \mathrm{mV}$ and plotted versus voltage. Top, Loss of $\beta 1(n=11)$ compared with littermate controls ( $n=11)$. Bottom, Loss of $\beta 1$ expression on an Scn2b null background $(n=30)$ compared with littermate controls $(n=11)$. WT, Wild type; het, heterozygous. Error bars indicate SEM.

in the comparison of double-null Purkinje cells to the $S c n 2 b$ null littermate control neurons. The percentage of noninactivating current was increased in the double nulls (from $0.92 \pm 0.23$ to $1.56 \pm 0.14 \% ; p=0.003)$. Inactivation was also significantly hyperpolarized in the double-null Purkinje cells (from $-64.2 \pm$ 1.0 to $-70.5 \pm 1.0 \mathrm{mV} ; p<0.001 ; n=9,22)$, without a concomitant increase in $k(5.9 \pm 0.1,5.8 \pm 0.1)$ (Fig. $8 B)$. This negative shift in $V_{1 / 2}$ is greater than that seen in HEK cells and CA3 cultures transfected with $\beta 4$. In the absence of the $\beta 4$-induced increase in the slope factor that was present in those cell types, the negative shift in inactivation is likely to suppress the window current at negative voltages. Not surprisingly, therefore, the persistent current measured 90-100 ms after step depolarizations to voltages below $0 \mathrm{mV}$ was not increased in either the single $S c n 1 b$ or double nulls $(p>0.1$ at all potentials between -40 and -10 $\mathrm{mV}$; data not shown).
Despite the lack of change in persistent current, inspecting the families of traces suggested that inactivation was not identical in cells from the four genotypes. For example, the time constant of decay at $0 \mathrm{mV}$ tended to be longer in the double-null cells (Fig. $8 C$ ). Because of this apparent slowing of inactivation, we also measured the "early" persistent current as the percentage of current remaining 25-30 ms after the depolarization. This duration is more than fivefold longer than the dominant time constant of inactivation in all genotypes, but inactivation has not yet reached a steady state by this time (Fig. $8 D$ ). Plots of this early persistent current normalized to the peak transient current versus voltage illustrated that the absence of $\beta 1$ increased the amount of early persistent current, both in $S c n 1 b$ null $(n=11)$ versus wild-type control $(n=11)$ (Fig. $8 E$, top) cells and in double-null $(n=30)$ versus $\operatorname{Scn} 2 b$ null $(n=11)$ (Fig. $8 E$, bottom) cells. As expected from the larger negative shift of the activation curve and the 
slower rate of inactivation, this effect was greater in the doublenull neurons, in which the persistent current at $-30 \mathrm{mV}$ was increased by $60 \%$. In fact, persistent currents $>3 \%$ were seen in $30 \%$ of the double-null neurons but in none of the cells from $\beta 2$ null littermates (Mann-Whitney $U$ test; $Z=-2.12 ; p=0.034$ ).

Together, the data indicate that the properties of $\mathrm{Na}$ channel complexes differ widely in $\mathrm{HEK}-\mathrm{Na}_{\mathrm{V}} 1.1$ cells, cultured CA3 neurons, and isolated Purkinje neurons, even with predicted similarities in $\beta$ subunit expression. In Purkinje neurons, loss of $\beta 1$ and $\beta 2$ hyperpolarizes the $V_{1 / 2}$ of inactivation relative to control more than in $\mathrm{HEK}-\mathrm{Na}_{\mathrm{V}} 1.1$ cells (control vs $\beta 4$ transfected) or even cultured CA3 neurons (control vs $\beta 4$ transfected) without an increase in the slope factor, producing a small window current. These differences are likely to result from cell-specific factors, such as $\alpha$-subunit identity, associated proteins, and posttranslational modifications. Nevertheless, in neurons, as well as in HEK$\mathrm{Na}_{\mathrm{V}} 1.1$ cells, if $\beta 4$ is the only $\beta$ subunit present, channels activate more readily, inactivation proceeds relatively slowly, and the noninactivating component of the availability curve is increased. Moreover, all these characteristics are apparently counteracted by expression of $\beta 1$.

\section{Discussion}

These experiments demonstrate that incorporation of $\beta 4$ subunits into $\mathrm{Na}_{\mathrm{V}} 1.1$ channel complexes in HEK cells increases the amplitudes of TTX-sensitive Na current, by activating channels at more negative voltages, increasing the amount of noninactivating current, and flattening the availability curve. $\beta 4$ expression thereby favors open over closed states at hyperpolarized potentials and open over inactivated states at depolarized potentials. Coexpression of $\beta 1$, or chimeric subunits including the extracellular and transmembrane domains of $\beta 1$, suppresses the $\beta 4$ induced changes, instead stabilizing closed states at hyperpolarized potentials and inactivated states at depolarized potentials. The idea that $\beta 1$ acts as a brake on channel opening favored by other $\beta$ subunits may be relevant to disease. For instance, although coexpression of $\beta 4$ with the GEFS + mutant subunit $\beta 1_{\mathrm{C} 121 \mathrm{~W}}$ generates channels that require even stronger depolarizations for activation than with wild-type $\beta 1$, the resultant channels fail to inactivate as readily as with wild type $\beta 1$. Thus, the $\beta 4-\beta 1-\mathrm{Na}_{\mathrm{V}} 1.1$ interaction described here raises the possibility that an unmasking of slowly inactivating or noninactivating $\mathrm{Na}$ current may contribute to disorders of hyperexcitability, such as epilepsy.

Experiments in hippocampal and Purkinje cells support the idea that $\beta 4$ also favors open states in neurons, although the changes were smaller and more variable than in $\mathrm{HEK}-\mathrm{Na}_{\mathrm{V}} 1.1$ cells. This variation is not surprising given the diversity of $\alpha$ subunits and the variety of $\mathrm{Na}$ channel-associated proteins present in neurons but not heterologous expression systems (Goldin, 2001). Nevertheless, overexpression of $\beta 4$ in hippocampal neurons, like in $\mathrm{HEK}-\mathrm{Na}_{\mathrm{V}} 1.1$ cells, consistently flattened inactivation curves and increased persistent currents. Moreover, in Purkinje neurons, which normally express $\beta 1, \beta 2$, and $\beta 4$ subunits, some differences between $S c n 1 b$ null and $S c n 1 b / S c n 2 b$ double-null neurons resembled the differences between $\alpha+\beta 1+\beta 4$ and $\alpha+\beta 4$ channels in $\mathrm{HEK}-\mathrm{Na}_{\mathrm{V}} 1.1$ cells, namely the shift in activation and the increase in noninactivating current. Unlike in $\mathrm{HEK}-\mathrm{Na}_{\mathrm{V}} 1.1$ cells, however, loss of $\beta 1$ and $\beta 2$ from Purkinje neurons did not change the slope of the availability curve and instead significantly shifted it to more hyperpolarized potentials. This discrepancy reinforces the idea that neurons include factors that heterologous expression systems lack, such as additional associated proteins and posttranslational modifications, which contribute to the overall properties of $\mathrm{Na}$ currents in the intact brain (Meadows and Isom, 2005).

\section{Resurgent Na current}

Although a peptide from the $\beta 4$ cytoplasmic tail replicates the open-channel block and unblock responsible for resurgent $\mathrm{Na}$ current (Grieco et al., 2005), expression of the intact $\beta 4$ subunit was insufficient to block channels either in HEK-Na 1.1 cells or in cultured neurons. Three explanations may account for this result: (1) Na channel complexes require posttranslational (or other) modification to permit open-channel block; (2) expression of an additional protein(s) may be necessary to allow block by $\beta 4$; or (3) the endogenous blocking protein in neurons with resurgent kinetics is not the $\beta 4$ subunit that we expressed but is instead a related protein with a cytoplasmic region that is structurally indistinguishable from the $\beta 4$ peptide. Regarding the first possibility, in neurons, $\alpha$ subunits are modulated by kinases and phosphatases (Cantrell and Catterall, 2001; Ahn et al., 2007), and even $\beta 4$ is the target of proteases (Miyazaki et al., 2007). Also noteworthy is that a broad-spectrum phosphatase abolishes the functionality of the blocking protein (Grieco et al., 2002). Regarding the latter two possibilities, because multiple proteins form the Na channel complex (Abriel and Kass, 2005), it is likely to be difficult in a heterologous expression system to replicate the native condition in neurons with resurgent current. Thus, whether the endogenous blocking protein is only structurally related to $\beta 4$, or is a form of $\beta 4$ itself, remains an open question.

\section{Persistent Na current}

At least two factors contribute to the ability of the $\beta 4$ subunit to raise the amplitude of persistent current in $\mathrm{HEK}-\mathrm{Na}_{\mathrm{V}} 1.1$ cells: the increase in window current by the modification of the activation and inactivation curves and the increase in open-state occupancy after maximal inactivation. Increases in persistent current have also been observed in $\mathrm{Na}_{\mathrm{V}}$ 1.2-expressing tsA-201 cells when $\beta 3$ is coexpressed; in those cells, $\beta 2$ alone does not modulate persistent current but augments the effect of $\beta 3$ (Qu et al., 2001). Thus, at least in certain cellular environments and with certain $\alpha$ subunits, $\beta 2, \beta 3$, and $\beta 4$ all promote persistent currents. In contrast, the subunit that consistently accelerates inactivation and/or decreases persistent current across $\mathrm{Na}$ channel $\alpha$ subunits is $\beta 1$ (Isom et al., 1992; Chen and Cannon, 1995; Smith et al., 1998; Meadows et al., 2002; Valdivia et al., 2002).

\section{Na channels, $\boldsymbol{\beta}$ subunits, and epilepsy}

In several $\mathrm{Na}$ channel $\alpha$ subunits, the efficacy of the fast inactivation gate (i.e., the cytoplasmic linker between domains III and IV) (Vassilev et al., 1988, 1989) is influenced by the C terminus. Mutations in the $\mathrm{C}$ terminus increase persistent current (Baroudi and Chahine, 2000; Choi et al., 2004) and/or slow the rate of fast inactivation (Wu et al., 2005), probably by disrupting an electrostatic interaction with the III-IV linker (Cormier et al., 2002), and many proteins that modulate $\mathrm{Na}$ channels depend on interactions with the $\mathrm{C}$ terminus (Abriel and Kass, 2005). Furthermore, wild-type $\beta 1$ directly interacts with the $C$ terminus of the $\mathrm{Na}_{\mathrm{V}} 1.1$ channel, and mutations that weaken this interaction generate GEFS + (Annesi et al., 2003; Spampanato et al., 2004). Together, these results suggest that the $\mathrm{C}$ terminus interacts with the III-IV linker in a $\beta 1$-dependent way to promote inactivation.

In the present study, however, the $\beta 1 / 4$ chimera facilitated inactivation and suppressed the effects of $\beta 4$ in much the same way as the intact $\beta 1$ subunit, suggesting that the intracellular 
domain of $\beta 1$ need not interact directly with either the Na channel C terminus or the III-IV itself. Instead, extracellular (or transmembrane) domains of $\beta 1$ may act allosterically to stabilize nonconducting states of the channel. This idea is consistent with studies indicating that the extracellular domain of $\beta 1$ is sufficient to accelerate inactivation of $\mathrm{Na}_{\mathrm{V}} 1.2$ and $\mathrm{Na}_{\mathrm{V}} 1.4$ (Chen and Cannon, 1995; McCormick et al., 1998, 1999).

The consequences of disrupting the interaction between $\beta 1$ and the rest of the channel complex are of clinical interest because several mutations in $\beta 1$ correlate with GEFS + (Wallace et al., 1998, 2002; Audenaert et al., 2003; Burgess, 2005; Scheffer et al., 2007). These include $\beta 1_{\mathrm{C} 121 \mathrm{~W}}$, which has been electrophysiologically characterized as a loss-of-function or reduction-of-function of $\beta 1$ (Wallace et al., 1998; Meadows et al., 2002; Tammaro et al., 2002). Our data demonstrate that $\mathrm{Na}$ currents resulting from coexpression of $\beta 1_{\mathrm{C} 121 \mathrm{~W}}$ with $\beta 4$ in $\mathrm{HEK}-\mathrm{Na}_{\mathrm{V}} 1.1$ cells are distinct from those arising from expression of $\beta 4$ or $\beta 1+\beta 4$ alone, suggesting that heterotrimers with emergent properties can indeed assemble. The activation curve suggests that such channels may require larger than normal stimuli to open, but once activated, they inactivate considerably less readily than channels with wild-type $\beta 1$, a feature that might promote repetitive firing. In fact, other mutations that lead to GEFS +, which are located in voltage-sensing regions of $\mathrm{Na}_{\mathrm{V}} 1.1$ (Escayg et al., 2000), also destabilize inactivation and increase persistent $\mathrm{Na}$ current (Lossin et al., 2002; Kahlig et al., 2006), raising the possibility that distinct mutations converge on a common mechanism to produce a specific disease phenotype.

Another link between reduction of $\beta 1$ function and epilepsy comes from the observation that $S c n 1 b$ null mice display spontaneous generalized seizures, although $S c n 1 b$ null hippocampal neurons show no significant changes in $\mathrm{Na}$ current relative to wild type (Chen et al., 2004). Our results, however, raise the possibility that $\mathrm{Na}$ channel gating in these mutants might be modified more extensively in brain regions that normally express $\beta 4$ as well as $\beta 1$, because changes in Na currents after loss of $\beta 1$ (and $\beta 2$ ) were readily detectable in Purkinje neurons, which express higher levels of $\beta 4$ than hippocampal neurons ( $\mathrm{Yu}$ et al., 2003). Nevertheless, because seizures are unlikely to originate in the cerebellum, it seems reasonable to speculate that channel opening may also be upregulated in at least one other brain region in Scn $1 b$ null mice. Consistent with this idea, cardiac myocytes (which express $\mathrm{Na}_{\mathrm{V}} 1.5$ and $\beta 4$ ) have more persistent current in $S c n 1 b$ null than wild-type cells, a condition that correlates with the long-QT syndrome (Lopez-Santiago et al., 2007).

\section{Physiological role of $\beta 4$}

The interaction among $\beta$ subunits suggests that the expression of $\beta 4$ is not a direct indicator of whether $\mathrm{Na}$ channel opening will be facilitated in any given neuron. Our results do, however, predict that an increased relative expression of $\beta 1$ may correlate with the stabilization of nonconducting states, whereas an increased relative expression of $\beta 4$ may correlate with more channel openings. In fact, several brain regions that strongly express $\beta 4$ (Yu et al., 2003; Oyama et al., 2006) have relatively large persistent currents, including the cerebellum (Llinás and Sugimori, 1980; Raman and Bean, 1997), thalamus (Parri and Crunelli, 1998), cortical pyramidal neurons (Cummins et al., 1994; Maurice et al., 2001), and striatum (Cepeda et al., 1995; Chao and Alzheimer, 1995). Along with our data, these observations support the idea that the complement of $\beta$ subunits defines the range of persistent current amplitudes that can be produced by the $\mathrm{Na}$ channel complex.

\section{References}

Abriel H, Kass RS (2005) Regulation of the voltage-gated cardiac sodium channel Nav1.5 by interacting proteins. Trends Cardiovasc Med 15:35-40.

Afshari FS, Ptak K, Khaliq ZM, Grieco TM, Slater NT, McCrimmon DR, Raman IM (2004) Resurgent Na currents in four classes of neurons in the cerebellum. J Neurophysiol 92:2831-2843.

Ahn M, Beacham D, Westenbroek RE, Scheuer T, Catterall WA (2007) Regulation of $\mathrm{Na}_{\mathrm{v}} 1.2$ channels by brain-derived neurotrophic factor, TrkB, and associated Fyn kinase. J Neurosci 27:11533-11542.

Alzheimer C, Schwindt PC, Crill WE (1993) Modal gating of $\mathrm{Na}^{+}$channels as a mechanism of persistent $\mathrm{Na}^{+}$current in pyramidal neurons from rat and cat sensorimotor cortex. J Neurosci 13:660-673.

Annesi G, Gambardella A, Carrideo S, Incorpora G, Labate A, Pasqua AA, Civitelli D, Polizzi A, Annesi F, Spadafora P, Tarantino P, Cirò Candiano IC, Romeo N, De Marco EV, Ventura P, LePiane E, Zappia M, Aguglia U, Pavone L, Quattrone A (2003) Two novel SCN1A missense mutations in generalized epilepsy with febrile seizures plus. Epilepsia 44:1257-1258.

Attwell D, Cohen I, Eisner D, Ohba M, Ojeda C (1979) The steady state TTX-sensitive ("window") sodium current in cardiac Purkinje fibres. Pflugers Arch 379:137-142.

Audenaert D, Claes L, Ceulemans B, Löfgren A, Van Broeckhoven C, De Jonghe P (2003) A deletion in SCN1B is associated with febrile seizures and early-onset absence epilepsy. Neurology 61:854-856.

Baroudi G, Chahine M (2000) Biophysical phenotypes of SCN5A mutations causing long QT and Brugada syndromes. FEBS Lett 487:224-228.

Brackenbury WJ, Davis TH, Chen C, Slat EA, Detrow MJ, Dickendesher TL, Ranscht B, Isom LL (2008) Voltage-gated $\mathrm{Na}^{+}$channel $\beta 1$ subunitmediated neurite outgrowth requires Fyn kinase and contributes to postnatal CNS development in vivo. J Neurosci 28:3246-3256.

Brown AM, Schwindt PC, Crill WE (1994) Different voltage dependence of transient and persistent $\mathrm{Na}+$ currents is compatible with modal-gating hypothesis for sodium channels. J Neurophysiol 71:2562-2565.

Burgess DL (2005) Neonatal epilepsy syndromes and GEFS+: mechanistic considerations. Epilepsia 46 [Suppl 10]:51-58.

Cantrell AR, Catterall WA (2001) Neuromodulation of $\mathrm{Na}+$ channels: an unexpected form of cellular plasticity. Nat Rev Neurosci 2:397-407.

Cepeda C, Chandler SH, Shumate LW, Levine MS (1995) Persistent Na+ conductance in medium-sized neostriatal neurons: characterization using infrared videomicroscopy and whole cell patch-clamp recordings. J Neurophysiol 74:1343-1348.

Chao TI, Alzheimer C (1995) Effects of phenytoin on the persistent $\mathrm{Na}+$ current of mammalian CNS neurons. Neuroreport 6:1778-1780.

Chen C, Cannon SC (1995) Modulation of Na+ channel inactivation by the beta 1 subunit: a deletion analysis. Pflugers Arch 431:186-195.

Chen C, Bharucha V, Chen Y, Westenbroek RE, Brown A, Malhotra JD, Jones D, Avery C, Gillespie PJ 3rd, Kazen-Gillespie KA, Kazarinova-Noyes K, Shrager P, Saunders TL, Macdonald RL, Ransom BR, Scheuer T, Catterall WA, Isom LL (2002) Reduced sodium channel density, altered voltage dependence of inactivation, and increased susceptibility to seizures in mice lacking sodium channel beta 2-subunits. Proc Natl Acad Sci U S A 99:17072-17077.

Chen C, Westenbroek RE, Xu X, Edwards CA, Sorenson DR, Chen Y, McEwen DP, O’Malley HA, Bharucha V, Meadows LS, Knudsen GA, Vilaythong A, Noebels JL, Saunders TL, Scheuer T, Shrager P, Catterall WA, Isom LL (2004) Mice lacking sodium channel $\beta 1$ subunits display defects in neuronal excitability, sodium channel expression, and nodal architecture. J Neurosci 24:4030-4042.

Chen Y, Yu FH, Sharp EM, Beacham D, Scheuer T, Catterall WA (2008) Functional properties and differential neuromodulation of $\mathrm{Na}(\mathrm{v}) 1.6$ channels. Mol Cell Neurosci 38:607-615.

Choi JS, Tyrrell L, Waxman SG, Dib-Hajj SD (2004) Functional role of the C-terminus of voltage-gated sodium channel Na.(v)1.8. FEBS Lett 572:256-260.

Cormier JW, Rivolta I, Tateyama M, Yang A-S Kass RS (2002) Secondary structure of the human cardiac $\mathrm{Na}+$ channel $\mathrm{C}$ terminus. Evidence for a role of helical structures in modulation of channel inactivation. J Biol Chem 277:9233-9241.

Crill WE (1996) Persistent sodium current in mammalian central neurons. Annu Rev Physiol 58:349-362.

Cummins TR, Xia Y, Haddad GG (1994) Functional properties of rat and 
human neocortical voltage-sensitive sodium currents. J Neurophysiol 71:1052-1064.

Dalby B, Cates S, Harris A, Ohki EC, Tilkins ML, Price PJ, Ciccarone VC (2004) Advanced transfection with Lipofectamine 2000 reagent: primary neurons, siRNA, and high-throughput applications. Methods 33:95-103.

Deschênes I, Neyroud N, DiSilvestre D, Marbán E, Yue DT, Tomaselli GF (2002) Isoform-specific modulation of voltage-gated $\mathrm{Na}(+)$ channels by calmodulin. Circ Res 90:E49-E57.

Do MT, Bean BP (2003) Subthreshold sodium currents and pacemaking of subthalamic neurons: modulation by slow inactivation. Neuron 39:109-120.

Escayg A, MacDonald BT, Meisler MH, Baulac S, Huberfeld G, AnGourfinkel I, Brice A, LeGuern E, Moulard B, Chaigne D, Buresi C, Malafosse A (2000) Mutations of SCN1A, encoding a neuronal sodium channel, in two families with GEFS+2. Nat Genet 24:343-345.

Felts PA, Yokoyama S, Dib-Hajj S, Black JA, Waxman SG (1997) Sodium channel alpha-subunit mRNAs I, II, III, NaG, Na6 and hNE (PN1): different expression patterns in developing rat nervous system. Brain Res Mol Brain Res 45:71-82.

Goldin AL (2001) Resurgence of sodium channel research. Annu Rev Physiol 63:871-894.

Grieco TM, Afshari FS, Raman IM (2002) A role for phosphorylation in the maintenance of resurgent sodium current in cerebellar Purkinje neurons. J Neurosci 22:3100-3107.

Grieco TM, Malhotra JD, Chen C, Isom LL, Raman IM (2005) Openchannel block by the cytoplasmic tail of sodium channel $\beta 4$ as a mechanism for resurgent sodium current. Neuron 45:233-244.

Herzog RI, Liu C, Waxman SG, Cummins TR (2003) Calmodulin binds to the $\mathrm{C}$ terminus of sodium channels $\mathrm{Na}_{\mathrm{v}} 1.4$ and $\mathrm{Na}_{\mathrm{v}} 1.6$ and differentially modulates their functional properties. J Neurosci 23:8261-8270.

Isom LL, De Jongh KS, Patton DE, Reber BF, Offord J, Charbonneau H, Walsh K, Goldin AL, Catterall WA (1992) Primary structure and functional expression of the beta 1 subunit of the rat brain sodium channel. Science 256:839-842.

Isom LL, Scheuer T, Brownstein AB, Ragsdale DS, Murphy BJ, Catterall WA (1995a) Functional co-expression of the beta 1 and type IIA alpha subunits of sodium channels in a mammalian cell line $\mathrm{J}$ Biol Chem 270:3306-3312.

Isom LL, Ragsdale DS, De Jongh KS, Westenbroek RE, Reber BF, Scheuer T, Catterall WA (1995b) Structure and function of the beta 2 subunit of brain sodium channels, a transmembrane glycoprotein with a CAM motif. Cell 83:433-442.

Kahlig KM, Misra SN, George AL Jr (2006) Impaired inactivation gate stabilization predicts increased persistent current for an epilepsy-associated SCN1A mutation. J Neurosci 26:10958-10966.

Khaliq ZM, Gouwens NW, Raman IM (2003) The contribution of resurgent sodium current to high-frequency firing in Purkinje neurons: an experimental and modeling study. J Neurosci 23:4899-4912.

Kim J, Ghosh S, Liu H, Tateyama M, Kass RS, Pitt GS (2004) Calmodulin mediates $\mathrm{Ca} 2+$ sensitivity of sodium channels. J Biol Chem 279:45004-45012.

Kuo CC, Chen RS, Lu L, Chen RC (1997) Carbamazepine inhibition of neuronal $\mathrm{Na}+$ currents: quantitative distinction from phenytoin and possible therapeutic implications. Mol Pharmacol 51:1077-1083.

Lampl I, Schwindt P, Crill W (1998) Reduction of cortical pyramidal neuron excitability by the action of phenytoin on persistent $\mathrm{Na}+$ current. J Pharmacol Exp Ther 284:228-237.

Llinás R, Sugimori M (1980) Electrophysiological properties of in vitro Purkinje cell somata in mammalian cerebellar slices. J Physiol 305:171-195.

Lopez-Santiago LF, Meadows LS, Ernst SJ, Chen C, Malhotra JD, McEwen DP, Speelman A, Noebels JL, Maier SK, Lopatin AN, Isom LL (2007) Sodium channel Scnlb null mice exhibit prolonged QT and RR intervals. J Mol Cell Cardiol 43:636-647.

Lossin C, Wang DW, Rhodes TH, Vanoye CG, George AL Jr (2002) Molecular basis of an inherited epilepsy. Neuron 34:877-884.

Lou JY, Laezza F, Gerber BR, Xiao M, Yamada KA, Hartmann H, Craig AM, Nerbonne JM, Ornitz DM (2005) Fibroblast growth factor 14 is an intracellular modulator of voltage-gated sodium channels. J Physiol 569:179-193.

Ma JY, Catterall WA, Scheuer T (1997) Persistent sodium currents through brain sodium channels induced by $\mathrm{G}$ protein $\beta \gamma$ subunits. Neuron 19:443-452.
Magistretti J, Alonso A (1999) Biophysical properties and slow voltagedependent inactivation of a sustained sodium current in entorhinal cortex layer-II principal neurons: a whole-cell and single-channel study. J Gen Physiol 114:491-509.

Magistretti J, Ragsdale DS, Alonso A (1999) High conductance sustained single-channel activity responsible for the low-threshold persistent $\mathrm{Na}^{+}$ current in entorhinal cortex neurons. J Neurosci 19:7334-7341.

Mantegazza M, Yu FH, Powell AJ, Clare JJ, Catterall WA, Scheuer T (2005) Molecular determinants for modulation of persistent sodium current by G-protein $\beta \gamma$ subunits. J Neurosci 25:3341-3349.

Maurice N, Tkatch T, Meisler M, Sprunger LK, Surmeier DJ (2001) $D_{1} / D_{5}$ dopamine receptor activation differentially modulates rapidly inactivating and persistent sodium currents in prefrontal cortex pyramidal neurons. J Neurosci 21:2268-2277.

McCormick KA, Isom LL, Ragsdale D, Smith D, Scheuer T, Catterall WA (1998) Molecular determinants of $\mathrm{Na}+$ channel function in the extracellular domain of the beta1 subunit. J Biol Chem 273:3954-3962.

McCormick KA, Srinivasan J, White K, Scheuer T, Catterall WA (1999) The extracellular domain of the betal subunit is both necessary and sufficient for betal-like modulation of sodium channel gating. J Biol Chem 274:32638-32646.

Meadows LS, Isom LL (2005) Sodium channels as macromolecular complexes: implications for inherited arrhythmia syndromes. Cardiovasc Res 67:448-458.

Meadows LS, Malhotra J, Loukas A, Thyagarajan V, Kazen-Gillespie KA, Koopman MC, Kriegler S, Isom LL, Ragsdale DS (2002) Functional and biochemical analysis of a sodium channel $\beta 1$ subunit mutation responsible for generalized epilepsy with febrile seizures plus type 1. J Neurosci 22:10699-10709.

Miyazaki H, Oyama F, Wong HK, Kaneko K, Sakurai T, Tamaoka A, Nukina N (2007) BACE1 modulates filopodia-like protrusions induced by sodium channel $\beta 4$ subunit. Biochem Biophys Res Commun 361:43-48.

Moran O, Nizzari M, Conti F (2000) Endogenous expression of the beta1A sodium channel subunit in HEK-293 cells. FEBS Lett 473:132-134.

Morgan K, Stevens EB, Shah B, Cox PJ, Dixon AK, Lee K, Pinnock RD, Hughes J, Richardson PJ, Mizuguchi K, Jackson AP (2000) Beta 3: an additional auxiliary subunit of the voltage-sensitive sodium channel that modulates channel gating with distinct kinetics. Proc Natl Acad Sci U S A 97:2308-2313.

Mori M, Konno T, Ozawa T, Murata M, Imoto K, Nagayama K (2000) Novel interaction of the voltage-dependent sodium channel (VDSC) with calmodulin: does VDSC acquire calmodulin-mediated Ca2 +-sensitivity? Biochemistry 39:1316-1323.

Oh Y, Sashihara S, Waxman SG (1994) In situ hybridization localization of the $\mathrm{Na}+$ channel $\beta 1$ subunit mRNA in rat CNS neurons. Neurosci Lett 176:119-122.

Oyama F, Miyazaki H, Sakamoto N, Becquet C, Machida Y, Kaneko K, Uchikawa C, Suzuki T, Kurosawa M, Ikeda T, Tamaoka A, Sakurai T, Nukina N (2006) Sodium channel beta4 subunit: down-regulation and possible involvement in neuritic degeneration in Huntington's disease transgenic mice. J Neurochem 98:518-529.

Parri HR, Crunelli V (1998) Sodium current in rat and cat thalamocortical neurons: role of a non-inactivating component in tonic and burst firing. J Neurosci 18:854-867.

Qu Y, Curtis R, Lawson D, Gilbride K, Ge P, DiStefano PS, Silos-Santiago I, Catterall WA, Scheuer T (2001) Differential modulation of sodium channel gating and persistent sodium currents by the $\beta 1, \beta 2$, and $\beta 3$ subunits. Mol Cell Neurosci 18:570-580.

Raman IM, Bean BP (1997) Resurgent sodium current and action potential formation in dissociated cerebellar Purkinje neurons. J Neurosci 17:4517-4526.

Raman IM, Bean BP (2001) Inactivation and recovery of sodium currents in cerebellar Purkinje neurons: evidence for two mechanisms. Biophys J 80:729-737.

Raman IM, Sprunger LK, Meisler MH, Bean BP (1997) Altered subthreshold sodium currents and disrupted firing patterns in Purkinje neurons of Scn8a mutant mice. Neuron 19:881-891.

Reber BF, Catterall WA (1987) Hydrophobic properties of the beta 1 and beta 2 subunits of the rat brain sodium channel. J Biol Chem 262:11369-11374.

Rusconi R, Scalmani P, Cassulini RR, Giunti G, Gambardella A, Franceschetti S, Annesi G, Wanke E, Mantegazza M (2007) Modulatory proteins can 
rescue a trafficking defective epileptogenic $\mathrm{Na}_{\mathrm{v}} 1.1 \mathrm{Na}^{+}$channel mutant. J Neurosci 27:11037-11046.

Scheffer IE, Harkin LA, Grinton BE, Dibbens LM, Turner SJ, Zielinski MA, Xu R, Jackson G, Adams J, Connellan M, Petrou S, Wellard RM, Briellmann RS, Wallace RH, Mulley JC, Berkovic SF (2007) Temporal lobe epilepsy and GEFS+ phenotypes associated with SCN1B mutations. Brain 130:100-109.

Silva AJ, Simpson EM, Takahashi JS, Lipp HP, Nakanishi S, Wehner JM, Giese KP, Tully T, Abel T, Chapman PF, Fox K, Grant S, Itohara S, Lathe F, Mayford M, McNamara JO, Morris RJ, Picciotto M, Roder J, Shin HS, et al. (1997) Mutant mice and neuroscience: recommendations concerning genetic background. Neuron 19:755-759.

Smith MR, Smith RD, Plummer NW, Meisler MH, Goldin AL (1998) Functional analysis of the mouse Scn8a sodium channel. J Neurosci 18:6093-6102.

Spampanato J, Kearney JA, de Haan G, McEwen DP, Escayg A, Aradi I, MacDonald BT, Levin SI, Soltesz I, Benna P, Montalenti E, Isom LL, Goldin AL, Meisler MH (2004) A novel epilepsy mutation in the sodium channel SCN1A identifies a cytoplasmic domain for $\beta$ subunit interaction. J Neurosci 24:10022-10034.

Stafstrom CE, Schwindt PC, Crill WE (1984) Repetitive firing in layer V neurons from cat neocortex in vitro. J Neurophysiol 52:264-277.

Taddese A, Bean BP (2002) Subthreshold sodium current from rapidly inactivating sodium channels drives spontaneous firing of tuberomammillary neurons. Neuron 33:587-600.

Tammaro P, Conti F, Moran O (2002) Modulation of sodium current in mammalian cells by an epilepsy-correlated beta 1-subunit mutation. Biochem Biophys Res Commun 291:1095-1101.

Tovar KR, Westbrook GL (2002) Mobile NMDA receptors at hippocampal synapses. Neuron 34:255-264.

Valdivia CR, Nagatomo T, Makielski JC (2002) Late Na currents affected by $\alpha$ subunit isoform and beta1 subunit co-expression in HEK293 cells. J Mol Cell Cardiol 34:1029-1039.

Vassilev P, Scheuer T, Catterall WA (1989) Inhibition of inactivation of single sodium channels by a site-directed antibody. Proc Natl Acad Sci U S A 86:8147-8151.

Vassilev PM, Scheuer T, Catterall WA (1988) Identification of an intracellular peptide segment involved in sodium channel inactivation. Science 241:1658-1661.

Wallace RH, Wang DW, Singh R, Scheffer IE, George AL Jr, Phillips HA, Saar K, Reis A, Johnson EW, Sutherland GR, Berkovic SF, Mulley JC (1998) Febrile seizures and generalized epilepsy associated with a mutation in the $\mathrm{Na}+$-channel beta1 subunit gene SCN1B. Nat Genet 19:366-370.

Wallace RH, Scheffer IE, Parasivam G, Barnett S, Wallace GB, Sutherland GR, Berkovic SF, Mulley JC (2002) Generalized epilepsy with febrile seizures plus: mutation of the sodium channel subunit SCN1B. Neurology $58: 1426-1429$.

Whitaker WR, Clare JJ, Powell AJ, Chen YH, Faull RL, Emson PC (2000) Distribution of voltage-gated sodium channel alpha-subunit and betasubunit mRNAs in human hippocampal formation, cortex, and cerebellum. J Comp Neurol 422:123-139.

Wittmack EK, Rush AM, Craner MJ, Goldfarb M, Waxman SG, Dib-Hajj SD (2004) Fibroblast growth factor homologous factor 2B: association with $\mathrm{Na}_{\mathrm{v}} 1.6$ and selective colocalization at nodes of Ranvier of dorsal root axons. J Neurosci 24:6765-6775.

Wong HK, Sakurai T, Oyama F, Kaneko K, Wada K, Miyazaki H, Kurosawa M, De Strooper B, Saftig P, Nukina N (2005) Beta subunits of voltagegated sodium channels are novel substrates of BACE1 and $\gamma$-secretase. J Biol Chem 280:11635-11640.

Wu FF, Gordon E, Hoffman EP, Cannon SC (2005) A C-terminal skeletal muscle sodium channel mutation associated with myotonia disrupts fast inactivation. J Physiol 565:371-380.

Young KA, Caldwell JH (2005) Modulation of skeletal and cardiac voltagegated sodium channels by calmodulin. J Physiol 565:349-370.

Yu FH, Westenbroek RE, Silos-Santiago I, McCormick KA, Lawson D, Ge P, Ferriera H, Lilly J, DiStefano PS, Catterall WA, Scheuer T, Curtis R (2003) Sodium channel $\beta 4$, a new disulfide-linked auxiliary subunit with similarity to $\beta 2$. J Neurosci 23:7577-7585. 